\title{
Entre Alma-Ata e a reforma sanitária brasileira: o Programa Nacional de Serviços Básicos de Saúde (Prev-saúde), 1979-1983
}

\author{
Between Alma-Ata and the Brazilian sanitary reform: the National \\ Basic Health Services Program (Prev-saúde), 1979-1983
}

\section{Carlos Henrique Paiva ${ }^{i}$ \\ ' Pesquisador, Observatório História e Saúde/Casa de Oswaldo Cruz/ Fiocruz. \\ Rio de Janeiro - RJ - Brasil orcid.org/0000-0002-7478-9628 \\ carlos.paiva@fiocruz.br}

\section{Gabriele Carvalho Freitasi \\ i Assistente de pesquisa Departamento de Pesquisa em História das Ciências e da Saúde/ Casa de Oswaldo Cruz/Fiocruz. Rio de Janeiro - RJ - Brasil orcid.org/0000-0002-2610-3003 gabi.cfreitas28@gmail.com}

Recebido em 2 abr. 2020.

Aprovado em 23 jul. 2020.
PAIVA, Carlos Henrique; FREITAS, Gabriele Carvalho. Entre Alma-Ata e a reforma sanitária brasileira: o Programa Nacional de Serviços Básicos de Saúde (Prev-saúde), 1979-1983. História, Ciências, Saúde - Manguinhos, Rio de Janeiro, v.28, n.2, abr.-jun. 2021, p.527-579.

Resumo

A história do Programa Nacional de Serviços Básicos de Saúde (Prevsaúde) se inicia em 1979, na articulação entre os Ministérios da Saúde, da Previdência e Assistência Social, do Interior e da Economia e a Organização Pan-americana da Saúde. Teve como objetivo reorganizar os serviços básicos de saúde em suas conexões com os demais níveis assistenciais. Internacionalmente, inscrevia-se no movimento deflagrado pela Conferência de Alma-Ata, de setembro de 1978. Em termos nacionais, representava tanto um acúmulo de conhecimento sobre organização dos serviços quanto um movimento que se adequava, em parte, à agenda da reforma sanitária brasileira. O Prev-saúde representou um conjunto de proposições para a reorganização da saúde que, naquele contexto, era consenso técnico entre burocracias e lideranças da reforma da saúde.

Palavras-chave: atenção primária à saúde; sistema de saúde; Prev-saúde; reforma sanitária brasileira; história da saúde pública.

\section{Abstract}

The history of the National Basic Health Services Program (Prev-saúde) begins in 1979 with a joint effort involving the Ministries of Health, Social Security and Assistance, Interior, and Economy, as well as the Pan-American Health Organization. The objective was to reorganize basic health services in their connections with other levels of care. Internationally, it was part of the movement sparked by the International Conference on Primary Health Care in Alma-Ata in September 1978. Domestically, the program represented an accumulation of knowledge about the organization of services as well as a movement that was partially adapted to Brazilian health reform agenda. Prev-saúde was a set of health proposals that represented a technical consensus between bureaucracies and leaders of health reform.

Keywords: primary health care; health system; Prev-saúde; Brazilian health reform; history of public health. 
$\mathrm{N}^{\mathrm{a} a}$ a década de 1970, notadamente na virada para a década seguinte, abre-se um contexto dos mais explorados pelos estudiosos da história brasileira. O processo de distensão do regime civil-militar e a abertura democrática, a crise fiscal do estado brasileiro e a formulação de um novo marco jurídico-constitucional para o país estão, certamente, entre os grandes temas que foram objeto de inúmeros e diferenciados aportes dos campos da história, das ciências sociais e da economia. Algumas dimensões desse mesmo processo, como a luta pelo acesso à saúde e, em particular, a definição da saúde como direito de cidadania, ganhariam destaque, em especial, na produção intelectual de sanitaristas e/ou de estudiosos associados aos campos da saúde pública e coletiva (Campos, 1988; Cohn, Edison, Karsch, 1991; Fleury, 1997).

Mais recentemente, contudo, os campos da história e das ciências sociais, não necessariamente em suas conexões com os campos da saúde pública/coletiva, têm registrado um crescente interesse sobre esses mesmos temas. Estudos que versam sobre a natureza do movimento pela reforma sanitária e a construção do Sistema Único de Saúde (SUS), bem como a construção de políticas de saúde específicas, merecem destaques nessa atualizada produção (Menicucci, 2007; Dowbor, 2009; Paiva, Teixeira, 2014). Os estudos demonstram que várias iniciativas e empreendimentos institucionais podem ser considerados importantes no processo histórico brasileiro de construção da ideia de direito à saúde e, também, na formulação de um renovado sistema de saúde no final da década de 1980.

Por fim, no terreno específico da história da atenção primária, não são muitos os estudos brasileiros que se debruçaram sobre a trajetória nacional. De um lado, predominam trabalhos do campo da saúde pública/coletiva que tomam como objeto experiências específicas da política. Goulart (2004, p.128), por exemplo, ao se ocupar das chamadas boas práticas em saúde da família, nos remete às iniciativas consideradas embrionárias de Curitiba (PR), Ibiá (MG), Vitória da Conquista (BA) e Niterói (RJ). Em decorrência de sua importante repercussão pública, Niterói, na região metropolitana do Rio de Janeiro, foi objeto de reflexões intelectualmente mais robustas por parte de alguns estudiosos (Teixeira, Monteiro, Miranda, 1999; Hubner, Franco, 2007).

De outro lado, estudos mais abrangentes, como o de Viana e Dal Poz (1998), tendem a compreender a conformação de uma atenção primária à saúde (APS) no país a partir da implementação, no início dos anos 1990, do Programa de Agentes Comunitários de Saúde e do Programa da Saúde da Família. Muitos e diferentes trabalhos, dissertações e teses do campo se juntaram a essa perspectiva. Já em abordagem histórica mais ampla, Fausto e Matta (2007) consideraram as experiências do Serviço Especial de Saúde Pública, a partir dos anos 1940; o contexto da reforma sanitária e da conferência de Alma-Ata, no final da década de 1970; e, por fim, a experiência de modelagem do Programa Nacional de Serviços Básicos de Saúde (Prev-saúde) como capítulos da construção de uma APS nacional.

Com foco no contexto do final da década de 1970, autores sobretudo do campo da história chamam a atenção para as distintas compreensões conceituais acerca da APS. Nesse período, apontam os estudiosos, o cenário internacional e diferentes contextos nacionais foram palcos de disputas entre uma APS seletiva e uma integral (Litsios, 2002; Cueto, 2004; Pires-Alves, Cueto, 2017; Cueto, Brown, Fee, 2019, p.170-202). O movimento de formulação de um programa nacional de serviços básicos de saúde para o Brasil se dá justamente nesse 
cenário que mistura contendas de ordem conceitual, esforços para formulação daquela que seria uma primeira política nacional de APS para o país e, adicionalmente, diligências em prol de uma reorganização do sistema de saúde brasileiro.

A história do Prev-saúde, como ficou conhecido o programa, inicia no final de 1979, quando um grupo de técnicos oriundo do Ministério da Saúde e do Ministério da Previdência e Assistência Social, sob a condução respectivamente de Waldir Arcoverde e de Jair Soares, contando também com o apoio dos ministérios do Interior e da Economia e também da Organização Pan-americana da Saúde (Opas), tomou como objetivo a formulação e implementação de um programa que fosse capaz de reorganizar as unidades básicas de saúde no país. Em termos internacionais, a iniciativa inscrevia-se no movimento deflagrado pela Conferência Internacional sobre Cuidados Primários de Saúde, conhecida simplesmente como Conferência de Alma-Ata, realizada no Cazaquistão, em setembro de 1978 (Pellegrini, set. 2005). Em termos nacionais, representava tanto certo acúmulo de conhecimentos relativos à organização dos serviços de saúde quanto um movimento que se adequava, em parte, à agenda do movimento pela reforma sanitária brasileira (Pires-Alves, Paiva, no prelo).

O documento do Prev-saúde é uma peça que permite que o leitor tenha acesso ao conjunto de proposições para a reorganização do sistema de saúde brasileiro que, no contexto da virada dos anos 1970 para os 1980, gozava de certo consenso técnico, tanto entre diferentes burocracias do Estado brasileiro quanto em parte do movimento social de reforma da saúde. Sua leitura, portanto, introduz o leitor em um conjunto de ideias e propostas sobre organização do sistema de saúde, com foco na atenção primária, por assim dizer, razoavelmente consagradas no cenário brasileiro dos anos 1970-1980.

\section{O Prev-saúde e seu contexto}

No final dos anos 1970, algumas ideias que circulavam no ambiente internacional, especialmente no contexto americano, expressavam-se vivamente em interesses, agendas e propostas defendidas por boa parte dos sanitaristas brasileiros. O acúmulo de publicações técnicas e seminários especializados, especialmente aqueles conduzidos pela Opas, apontava há décadas para um delicado quadro sanitário que se caracterizava pela inadequada cobertura assistencial e pela incidência de doenças típicas da pobreza, como aquelas relacionadas com parasitas e com água contaminada (Cueto, 2006; Paiva, PiresAlves, Hochman, 2008).

Em que pesem as diferenças de enfoque teórico e enquadramento técnico acerca dos desafios sanitários já identificados, havia certo consenso técnico de que as melhores formas de enfrentamento dos problemas de saúde deveriam envolver, entre outras coisas, iniciativas no campo do planejamento e da avaliação de ações e políticas, exigindo, por sua vez, a administração coordenada dos serviços de saúde, com uma necessária articulação técnicopolítica dos âmbitos nacional e local, assim como o enfrentamento da separação entre as ações de prevenção e cura (Cueto, 2006).

A confiança em formas de intervenção programadas, organizadas segundo metodologias do campo do planejamento, era parte fundamental das ideias e práticas dos sanitaristas 
nas diferentes estratégias de enfrentamento dos problemas sanitários naquele período. Aos postulados, por assim dizer, racionalizadores, somava-se mais uma ideia-força: o aumento da cobertura dos serviços assistenciais de saúde. Em termos gerais, essas ideias organizaram as pautas institucionais do período, muito frequentemente, também associadas a perspectivas críticas quanto aos arranjos institucionais centralizadores e verticais na saúde. Não raro, registramos, igualmente, críticas contundentes quanto ao uso de tecnologias consideradas complexas e economicamente dispendiosas (Cueto, 2004).

Em termos internacionais, esse contexto vincula-se ao estabelecimento, em 1977, da meta "Saúde para todos no ano 2000" e, em setembro de 1978, à Conferência de AlmaAta, que defendeu as abordagens baseadas na APS como o principal meio para cumpri-la (Litsios, 2002; Cueto, 2004). No ambiente brasileiro, tal contexto de críticas e propostas político-organizacionais tornou-se parte fundamental do que se convencionou chamar de movimento sanitário brasileiro. Suas origens mais remotas, a partir dos anos 1950, situam-se no contexto de debate sobre educação médica com foco na medicina preventiva. A partir da década seguinte, agregaram-se debates e iniciativas com vistas à constituição de um sistema de saúde capaz de ampliar a cobertura dos serviços assistenciais. No contexto dos anos 1970, sobretudo em sua segunda metade, tais ideias e propostas, contando, algumas vezes, com importantes mudanças de enfoque teórico e político, radicalizam-se e assumem a feição, na década seguinte, de uma proposição concreta para um renovado sistema de saúde. A ideia de construção de um sistema de saúde universal e democrático, por fim, ganha sentido no cenário de abertura política e restituição da democracia naquele fim de década (Fleury, 1997; Escorel, 1999).

É importante ressaltar que desde meados da década de 1970, por intermédio de iniciativas como o segundo Plano Nacional de Desenvolvimento e políticas específicas, como o Programa de Interiorização de Ações de Saúde e Saneamento, o governo federal procurava enfrentar a perda de apoio e popularidade decorrente dos efeitos sociais da degradação da economia. Abria-se espaço, portanto, no interior do Estado brasileiro, para uma agenda que se poderia chamar de social. É por esse caminho que, segundo Escorel (1999), personagens afinados com as ideias de um nascente movimento pela reforma sanitária preencheriam, pouco a pouco, espaços de decisão na burocracia técnica estatal. A partir de diferentes lugares institucionais, médicos de posições progressistas e inovadoras procuraram introduzir, progressivamente, transformações no sistema de saúde do país. O Prev-saúde pode ser também compreendido como parte dos primórdios desse processo.

Em termos gerais, pode-se dizer que o Prev-saúde, naquele contexto de virada de década, representava a organização de uma agenda de questões que conjugava tanto uma proposta de extensão da cobertura de alcance nacional quanto uma série de atributos e iniciativas "racionalizadoras", razoavelmente consensuadas entre os diferentes grupos que constituíam a saúde pública brasileira. Suas nove diretrizes operacionais ${ }^{1}$ revelam ainda a existência de um acervo conceitual e de expertises organizacionais que, sem dúvida, encontraram acolhida na experiência de formulação de um sistema único de saúde anos depois. Do ponto de vista estritamente técnico-organizacional, contudo, é preciso atentar que o Prev-saúde representou um esforço institucional de construção de uma proposta racionalizadora para o então recém-implantado Sistema Nacional de Saúde. ${ }^{2}$ 
No entanto, como veremos a seguir, o relativo consenso técnico em torno da proposta inicial do programa não foi suficiente para blindá-lo contra a forte oposição que sofreria ao longo de seu processo de formulação. Ao privilegiar a criação de uma rede pública de unidades básicas, os formuladores do programa transformaram-se em alvos de grupos ligados aos interesses da rede privada de hospitais, ciosos quanto à implantação de um programa que, ao fim e ao cabo, pudesse trazer consequências consideradas negativas para a vigência da política de transferências de recursos públicos para a rede privada. Não é coincidência que a Federação Brasileira de Hospitais, uma entidade associativa fundada em meados dos anos 1960, tenha se manifestado publicamente contra o programa (Mello, 1981, p.26).

A Federação Brasileira de Hospitais não foi o único ator que fez oposição organizada ao Prev-saúde. Interesses vigentes no Instituto Nacional de Assistência Médica da Previdência Social (Inamps) também trabalharam contra a formulação e implantação da proposta, o que revela as imensas dificuldades de trânsito da proposição nas próprias estruturas de poder do Estado. Com a chancela da Presidência do Inamps, à época sob a condução de Hari Valdir Graeff, por exemplo, saiu do instituto uma proposta de criação de um seguro opcional público que, expandindo a rede privada conveniada, supostamente promoveria a construção de uma rede hospitalar mais bem organizada para aqueles que pudessem pagar (Mello, 1981; Pires-Alves, Paiva, no prelo).

Parece-nos que a história do Prev-saúde pode nos revelar, pelo menos, duas coisas importantes: a primeira delas é que, já àquela altura, os interesses contrários ao fortalecimento das instituições públicas de saúde se encontravam suficientemente organizados e com inquestionável poder de veto. De outra parte, que parcela do movimento pela reforma sanitária, já em curso, pode ter aprendido lições importantes diante do processo que levou à derrocada do Prev-saúde. Uma sempre difícil posição que combinasse soluções conciliatórias, sem prejuízo para algumas proposições audaciosas como, por exemplo, a defesa do direito à saúde, colocava-se como pauta necessária para os movimentos de luta que se expressariam na oitava Conferência Nacional de Saúde e no processo constituinte. Nesse sentido, o Prevsaúde pode ser encarado como um dos cenários de aprendizado político-institucional acerca de difíceis lutas que se travariam, com relativo êxito, nos anos seguintes.

\section{O Prev-saúde, 1981-1986}

Uma primeira versão do Prev-saúde veio formalmente a público no contexto da sétima Conferência Nacional de Saúde, realizada em março de 1980. Recebida com boa dose de estranhamento por parte daqueles que estavam em uma conferência ainda habitada por autoridades governamentais, técnicos e representantes dos mais diversos interesses econômicos e políticos setoriais, acabou por escancarar as tensões do debate entre Estado e interesses privados na saúde. O centro do estranhamento dizia respeito ao fato de o projeto ter sido considerado demasiado estatizante na previsão de ações e serviços básicos de saúde. Como nos apontam Luiz Cordoni Jr. e Márcio Almeida (1980), esse não era um debate simples e desprovido de importância naquele contexto em que o movimento sanitário organizava suas bases de atuação política. Para os autores: 
Durante o desenrolar dos trabalhos da VII Conferência Nacional de Saúde percebia-se um certo clima de incredulidade. As análises e comentários giravam, invariavelmente, em torno da proposta de implantação do Programa Nacional de Serviços Básicos de Saúde (Prev-saúde) apresentada pelos Ministérios da Saúde e da Previdência e Assistência Social (Cordoni Jr., Almeida, 1980, p.11).

A dúvida e a perplexidade se deram, essencialmente, pela dificuldade em assimilar que o Estado realmente assumiria os compromissos ali apresentados. O conteúdo dos anais da conferência nos ajuda a ter dimensão da relevância da proposta do Prev-saúde naquele contexto, uma vez que ali fica claro que o objetivo daquele espaço era ampliar o debate em torno das estratégias para implantação do programa. Isto é, torná-lo viável politicamente (Brasil, 1980, p.3).

Em termos formais, o texto da proposta apresentada tomava como base os objetivos do terceiro Plano Nacional de Desenvolvimento. Ajustava-se, portanto, às expectativas de resposta do regime ao quadro de crise social que, àquela altura, não se podia mais camuflar. Assinado pelos ministros da Saúde e da Previdência e Assistência Social, compunha um ambicioso rol de ações do governo federal voltadas para a reorganização geral dos serviços prestados pelo setor da saúde.

O texto do projeto apresenta como justificativa para sua criação a crescente insatisfação com os resultados, considerados lentos, das iniciativas apresentadas até aquele momento, principalmente no que dizia respeito à cobertura de serviços assistenciais, redução de doenças e danos de significado sociossanitário. Outro ponto fundamental que o conteúdo do documento problematiza é a multiplicidade de instituições existentes que atuavam de forma descoordenada, o que resultaria em ações duplicadas, crescente desperdício de recursos e perda de prestigio e credibilidade social do setor da saúde.

Nessa linha, o Prev-saúde se apresentava como uma proposta governamental para reordenar a oferta de serviços de saúde afinada aos debates e às iniciativas de "racionalização" da organização sanitária típicas daquele contexto. Revelava, ainda, alinhamento às formulações da Conferência de Alma-Ata, que consagrou, em termos internacionais, a APS como ponto fundamental para pensar sistemas nacionais de saúde.

Tratava-se de tema caro à militância pela saúde e, como vimos, também central na proposta do programa. A Associação de Médicos Sanitaristas do Estado de São Paulo, certamente imbuída das mais altas expectativas quanto à estatização dos serviços de saúde, considerou que "o Inamps financia o lucro dos empresários e dos hospitais. O Prev-saúde garante a manutenção do modelo privatizante de assistência médica, cujo objetivo é o lucro" (Mello, 1981, p.26). Crítica semelhante em relação a uma imaginada presença daninha do setor privado na área da saúde foi seguida pelo Instituto Oswaldo Cruz, pelo Sindicato dos Médicos e pelo Conselho Regional de Medicina do Estado de São Paulo (Mello, 1981, p.26).

Os secretários estaduais de Saúde do Norte e Nordeste, por sua vez, consideraram que era "necessário dar ênfase à ideia de ser o setor público o principal responsável, complementarmente, à participação do setor privado em campo de ação que deve ser perfeitamente limitado" (Mello, 1981, p.26). Tratava-se, certamente, de um posicionamento mais brando quanto à presença do setor privado na saúde, se comparado ao de outros atores. 
Já a Comissão de Saúde da Câmara dos Deputados compreendeu que "as atividades lucrativas mantidas com financiamento público deverão ser substituídas a médio prazo, por serviços públicos ... Enquanto for necessária a contratação de serviços com rede hospitalar privada, deverá ser abolida a modalidade de pagamento por unidade de serviço, reconhecidamente corruptora e incontrolável" (Mello, 1981, p.26).

Como se pode ver, o principal ponto de divergência, no que concerne à expectativa de boa parte dos atores, consistia no fato de não estar suficientemente claro o papel do setor privado na reorganização da assistência proposta pelo programa. A proposta de extensão da cobertura em termos nacionais, inevitavelmente, abria a possibilidade concreta de aumento progressivo da presença da iniciativa privada no sistema de saúde brasileiro. Adicionalmente, como uma proposta de reorganização da "rede de serviços básicos de saúde", o texto produzia dúvidas quanto ao papel a ser desempenhado pelas secretarias estaduais e municipais de Saúde e, em especial, sobre como operaria o acesso da população e funcionamento dos chamados nível secundário e terciário (Cebes, 1981, p.23).

Os sucessivos posicionamentos críticos quanto ao conteúdo do projeto estimularam um processo de revisão do texto por parte dos técnicos e, por conseguinte, a redação de diferentes versões em relação à proposta original. Além daquela distribuída no contexto da sétima Conferência Nacional de Saúde, é possível identificar uma versão de julho de 1980, outra de agosto, e uma terceira de setembro desse mesmo ano. A derradeira versão do projeto teria sido elaborada em dezembro de 1980. Há, contudo, divergências com relação à quantidade de versões que foram produzidas, provavelmente mais de dez.

A versão que aqui divulgamos nos parece ser de meados de setembro de 1980, visto que em uma busca na revista Saúde em Debate, vinculada ao Centro Brasileiro de Estudos de Saúde (Cebes), foi possível identificar notícias que traziam informações sobre a circulação e o conteúdo desse material. Nos referidos materiais encontramos relatos como "portanto, o projeto original do Prev-saúde, datado de julho de 80" (Oliveira, 1981, p.38), ou ainda "nesse interim [entre julho e setembro de 1980] duas versões do programa vieram à luz" (p.38). "Em outubro do ano passado [1980], os Ministérios da Saúde e da Previdência Social enviaram a diversas instituições um ante-projeto do Programa Nacional de Serviços Básicos de Saúde (Prev-saúde)" (Cebes, 1981, p.21). Há uma certa inconsistência quanto às possíveis datas das versões do documento; apesar disso, o que nos leva a situar a versão que apresentamos em setembro de 1980 são os trechos transcritos nesses textos, que, comparados ao documento que temos em mãos, apresentam similaridades (Cebes, 1981; Oliveira, 1981).

O documento, como era de esperar, apresenta detalhadamente a organização do programa. Suas 76 páginas estão divididas em seis partes, a saber: Introdução; Abrangência, objetivos e prioridades; Diretrizes gerais; Caracterização do modelo de prestação de serviços; Estratégia de desenvolvimento do programa; Metas, custos e financiamento.

A leitura atenta de suas "Diretrizes gerais" nos permite ter noção da amplitude e do grau de organização e estrutura necessários para colocar um projeto dessa magnitude em andamento. As diretrizes compreendem: regionalização; universalização do atendimento; tecnologia apropriada e procedimentos simplificados; utilização intensiva de profissionais generalistas e pessoal auxiliar; reorganização administrativa; máxima produtividade dos serviços; integralização das ações de saúde; participação comunitária; e articulação intrassistêmica. 
Ao final, o leitor tem acesso também às tabelas com informações acerca das metas para a expansão e recuperação da rede de serviços, os custos de investimento em um período de seis anos (1981-1986) e uma previsão da capacidade de serviços instaladas até o final da vigência imaginada do programa.

Por fim, cabe sinalizar que essa versão do Prev-saúde merece ser publicizada por se tratar de um componente importante do contexto da história recente da saúde no Brasil. Ela traz contribuições para o entendimento de alguns caminhos que levaram à constituição do atual SUS, além de ilustrar conflitos importantes travados, em especial entre o setor público e o privado, e o papel do Estado como formulador de políticas.

\section{NOTAS}

${ }^{1}$ Regionalização; universalização do atendimento; tecnologia apropriada e procedimentos simplificados; utilização intensiva de pessoal generalista e auxiliar; reorganização administrativa, com foco na integração interinstitucional e na descentralização; máxima produtividade dos serviços, com foco na cobertura populacional; integralização das ações de saúde, compreendida como ações de saúde com foco nas dimensões biológica, psíquica e social; participação comunitária, de modo a permitir a influência da comunidade no que concerne ao planejamento, execução e controle dos serviços prestados; e, finalmente, a articulação intrassistêmica, compreendida como o necessário estabelecimento de vínculos entre os níveis assistenciais do sistema de saúde (Brasil, set. 1980, p.3).

${ }^{2}$ O Sistema Nacional de Saúde, criado pelo decreto n.6.229, de 17 de julho de 1975, configurou-se como a primeira tentativa concreta de organização do aparato institucional da saúde, dentro dos limites permitidos pelo contexto político do regime militar-civil (1964-1985). Adicionalmente, representou o reconhecimento oficial de algumas das imperfeições na organização dos serviços de saúde do país naquele período (Schechtman et al., 2002; Torres, 2020).

\section{REFERÊNCIAS}

BRASIL. Ministério da Saúde. Conferência Nacional de Saúde, 7. Anais... Brasília: Ministério da Saúde, 1980.

BRASIL. Ministério da Saúde/Ministério da Previdência e Assistência Social. Programa Nacional de Serviços Básicos de Saúde PREVSAÚDE. Brasília: Ministério da Saúde/ Ministério da Previdência e Assistência Social, set. 1980 .

CAMPOS, Gastão Wagner de Sousa. A reforma sanitária necessária. In: Berlinguer, Giovanni; Teixeira, Sonia Fleury; Campos, Gastão Wagner de Sousa. Reforma sanitária: Itália e Brasil. São Paulo: Editora Cebes; Hucitec, 1988. p.179-194.

CEBES, Centro Brasileiro de Estudos de Saúde. Prev-saúde. Saúde em Debate, n.12, p.21-25, 1981. Disponível em: http://docvirt.com/ docreader.net/SaudeDebate/3454. Acesso em: 9 mar. 2021.

COHN, Amélia; EDISON, Jacobi R.; KARSCH, Ursula. A saúde como direito e como serviço. São Paulo: Cortez, 1991.

CORDONI JR., Luiz; ALMEIDA. Márcio José de. VII Conferência Nacional de Saúde: um passo adiante?!. Saúde em Debate, n.10, p.11-15, 1980. Disponível em: http://docvirt.com/docreader. net/SaudeDebate/3174. Acesso em: 10 mar. 2021.

CUETO, Marcos. O valor da saúde: história da Organização Pan-americana da Saúde. Rio de Janeiro: Editora Fiocruz, 2006.

CUETO, Marcos. The origins of primary health care and selective primary health care. American Journal of Public Health, v.94, n.11, p.1864-1874, 2004.

CUETO, Marcos; BROWN, Theodore; FEE, Elizabeth. The World Health Organization: a history. Cambridge: Cambridge University, 2019.

DOWBOR, Monika. Da inflexão préconstitucional ao SUS municipalizado. Lua Nova, n.78, p.158-222, 2009.

ESCOREL, Sarah. Reviravolta na saúde: origem e articulação do movimento sanitário. Rio de Janeiro: Editora Fiocruz, 1999.

FAUSTO, Márcia Cristina Rodrigues; MATTA, Gustavo Corrêa. Atenção primária à saúde: histórico e perspectivas. In: Morosini, Márcia Valéria Guimarães Cardoso (org.). Modelos de 
atenção e a saúde da família. Rio de Janeiro: EPSJV/Fiocruz, 2007. p.43-67.

FLEURY, Sonia. A questão democrática na saúde. In: Fleury, Sonia (org.). Saúde e democracia: $a$ luta do Cebes. São Paulo: Lemos Editorial, 1997. p.25-44.

GOULART, Flávio A. de Andrade. Círculos virtuosos e boas práticas em saúde da família. In: Fernandes, Afra Suassuna; Seclen-Palacin, Juan A. (org.). Experiências e desafios da atenção básica e saúde familiar: caso Brasil. Brasília, DF: Organização Pan-Americana da Saúde, 2004. p.127-142.

HUBNER, Luiz Carlos Moreira; FRANCO, Túlio Batista. O programa médico de família de Niterói como estratégia de implementação de um modelo de atenção que contemple os princípios e diretrizes do SUS. Physis, v.17, n.1, 173-191, 2007.

LITSIOS, Socrates. The long and difficult road to Alma-Ata: a personal reflection. Intenational Journal of Health Services, v.32, n.4, p.709-732, 2002.

MELLO, Carlos Gentile. Prev-saúde: vida, paixão e morte. Saúde em Debate, n.12, p.25-26, 1981. Disponível em: http://docvirt.com/docreader. net/SaudeDebate/3458. Acesso em: 9 mar. 2021.

MENICUCCI, Telma Maria Gonçalves. Público e privado na política de assistência à saúde no Brasil: atores, processos e trajetórias. Rio de Janeiro: Editora Fiocruz, 2007.

OLIVEIRA, Jaime Antônio de Araújo. Em defesa do Prev-saúde ou, VII Conferência Nacional de Saúde: um passo adiante. Saúde em Debate, n.11, p.38-44, 1981. Disponível em: http://docvirt. com/docreader.net/SaudeDebate/3323. Acesso em: 10 mar. 2021.

PAIVA, Carlos Henrique Assunção; PIRES-ALVES, Fernando; HOCHMAN, Gilberto. A cooperação técnica Opas-Brasil na formação de trabalhadores para a saúde (1973-1983). Ciência e Saúde Coletiva, v.13, n.3, p.819-829, 2008.
PAIVA, Carlos Henrique Assunção; TEIXEIRA, Luiz Antonio. Reforma sanitária e a criação do Sistema Único de Saúde: notas sobre contextos e autores. História, Ciências, Saúde-Manguinhos, v.21, n.1, p.15-35, 2014.

PELLEGRINI, Alberto. Entrevista concedida a Carlos Henrique Paiva e Gilberto Hochman. Transcrita por Andrea Ribeiro. Rio de Janeiro: COC/Fiocruz, set. 2005. Disponível em: http:// observatoriohistoria.coc.fiocruz.br/php/level.ph p?lang $=$ pt\&component $=43 \&$ item $=6$. Acesso em: 9 mar. 2021.

PIRES-ALVES, Fernando Antônio; CUETO, Marcos. A década de Alma-Ata: a crise do desenvolvimento e a saúde internacional. Ciência e Saúde Coletiva, v.22, n.7, p.2135-2144, 2017.

PIRES-ALVES, Fernando A.; PAIVA, Carlos Henrique A. Entre a ausência em Alma-Ata e o Prev-Saúde: a atenção. História, Ciências, SaúdeManguinhos, no prelo.

SCHECHTMAN, Alfredo et al. Evolução das políticas e do sistema de saúde no Brasil. In: Finkelman, Jacobo (org.). Caminhos da saúde pública no Brasil. Rio de Janeiro: Editora Fiocruz, 2002. p.235-313.

TEIXEIRA, Suely C.S.; MONTEIRO, Valéria de O.; MIRANDA, Verônica A. Programa médico de família no município de Niterói. Estudos Avançados, v.13, n.35, p.147-155, 1999.

TORRES, Christiane de Roode. O processo de construção do Sistema Nacional de Saúde: tradição e inovação na política de saúde brasileira (19401980). Tese (Doutorado) - Fundação Oswaldo Cruz, Rio de Janeiro, 2020.

VIANA, Ana Luiza; DAL POZ, Mario Roberto. A reforma do sistema de saúde no Brasil e o Programa de Saúde da Família. Physis: Revista de Saúde Coletiva, v.8, n.2, p.11-48, 1998.

\section{$\rightarrow \rightarrow \rightarrow r<$}


[capa]

\section{PROGRAMA NACIONAL DE SERVIÇOS BÁSICOS DE SAÚDE \\ PREVSAUDE}

\section{1-1986}

\section{MINISTÉRIO DA SAÚDE MINISTÉRIO DA PREVIDÊNCIA E ASSISTÊNCIA SOCIAL \\ [página não numerada]}

ÍNDICE Página

1. INTRODUÇÃO . .1

2. ABRANGÊNCIA, OBJETIVOS E PRIORIDADES …..............................................................

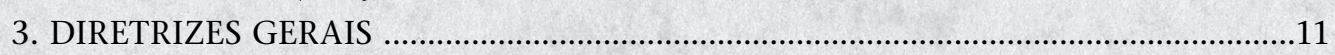

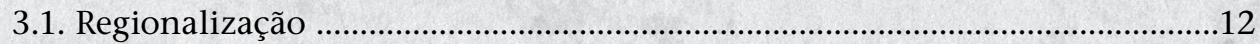

3.2. Universalização do Atendimento ..........................................................................12

3.3. Tecnologia Apropriada e Procedimentos Simplificados ..................................12

3.4. Utilização Intensiva de Profissionais Generalistas e Pessoal Auxiliar ............12

3.5. Reorganização Administrativa .........................................................................13

3.6. Máxima Produtividade dos Serviços ..................................................................13

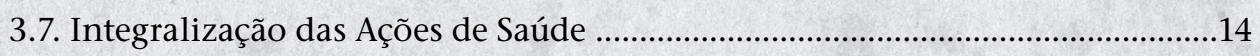

3.8. Participação Comunitária ...................................................................................14

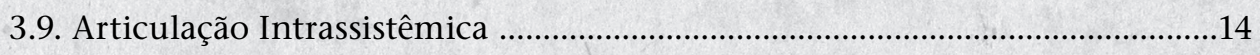

4. CARACTERIZAÇÃO DO MODELO DE PRESTAÇÃO DE SERVIÇOS ………................15

4.1. Organização da Rede de Serviços Básicos ............................................................16

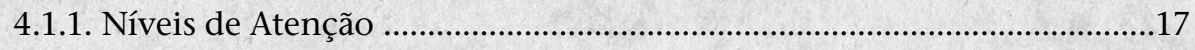

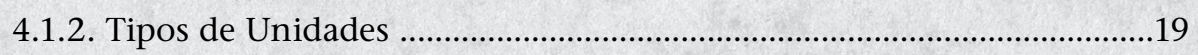

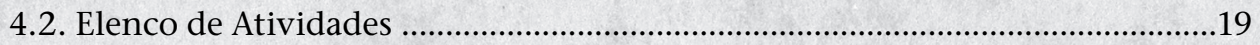

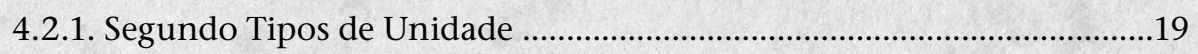

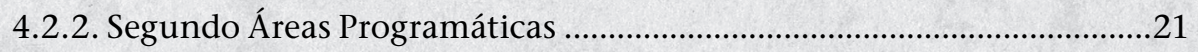

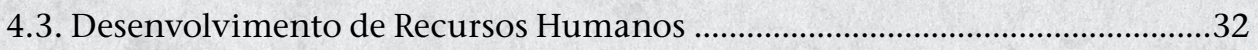

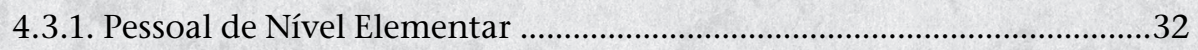

4.3.2. Pessoal de Nível Médio ................................................................................33 
4.3.3. Pessoal de Nível Superior .33

4.3.4. Administração de Pessoal

[página não numerada]

4.3.5. Supervisão e Educação Continuada .35

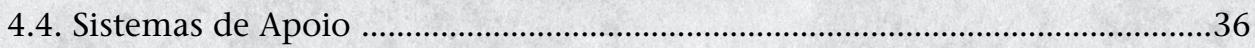

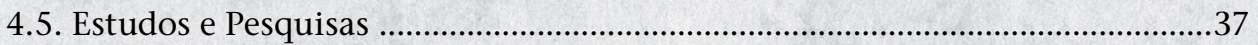

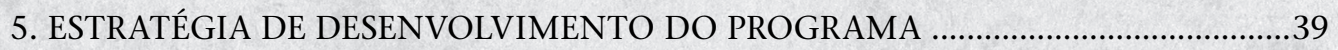

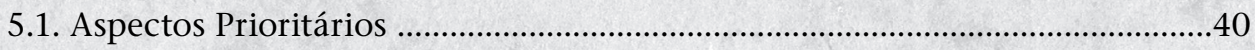

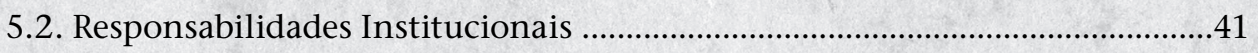

5.3. Mecanismos de Integração, Coordenação e Gerência .....................................45

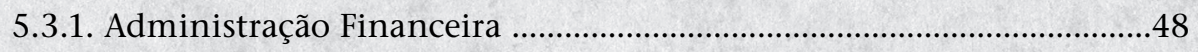

5.4. Articulação com outros Programas e Instituições ..............................................49

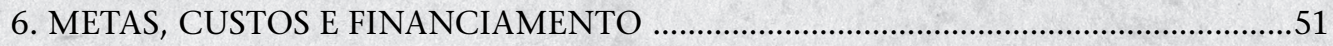

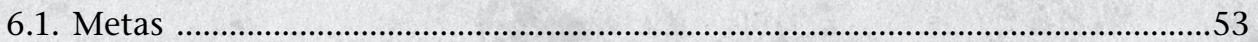

6.1.1. Serviços Básicos de Atendimento às Pessoas ............................................53

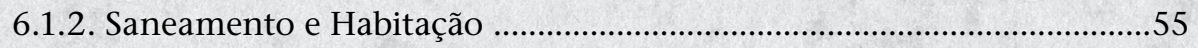

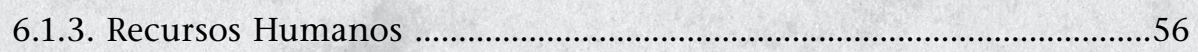

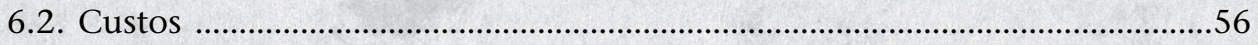

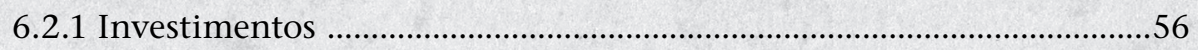

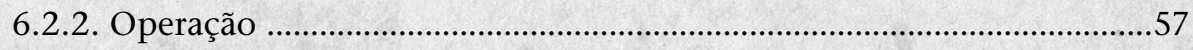

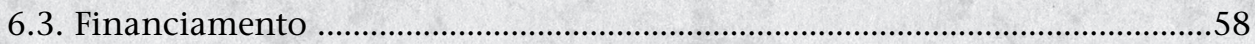

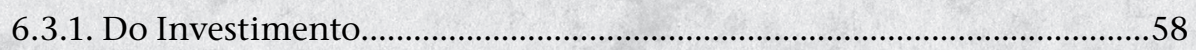

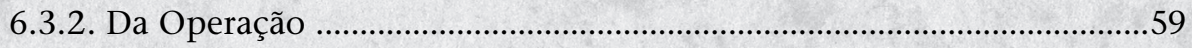

[página não numerada]

1. INTRODUÇÃO

[página 1]

O objetivo síntese do III Plano Nacional de Desenvolvimento enfatiza a necessidade de construção de uma sociedade desenvolvida e livre, em benefício do povo, dentro do princípio de que o objetivo democrático é indissociável da ideia básica de melhorar a qualidade de vida de todos os brasileiros.

Para a consecução desses propósitos da política de desenvolvimento, o setor saúde tem especial contribuição a oferecer, particularmente traduzida no aperfeiçoamento dos seus serviços e instrumentos de ação, reorientando-os para o atendimento preferencial das necessidades básicas de saúde da população. 
No contexto geral da administração pública brasileira, a intensificação das medidas voltadas a esse aprimoramento teve um de seus grandes marcos no Decreto-Lei $\mathrm{n}^{\circ} 200$, de 1967 , que definiu as diretrizes para a reforma administrativa na área federal e os instrumentos racionalizadores da atuação governamental. Dentre esses, sobressai o da descentralização administrativa, preconizando, inclusive, a transferência da execução das atividades da administração federal para as Unidades Federadas, os Municípios e as entidades privadas, reservadas ao nível federal as funções de definição de política e de coordenação e supervisão da execução de atividades.

A criação do Conselho de Desenvolvimento Social, em 1974, representou outro evento significativo para o aprimoramento da ação do governo na área social, como instrumento de compatibilização dos vários planos setoriais às diretrizes da política nacional de desenvolvimento.

Mais recentemente, nos termos da Lei $\mathrm{n}^{\circ}$ 6.229, de 1975, foi estabelecido o Sistema Nacional de Saúde, com a definição das competências dos diversos componentes que o integram. Considera-se importante salientar, no contexto da referida Lei, a inequívoca disposição de utilizar a colaboração de Estados e Municípios, mesmo naquelas ações ainda consideradas de responsabilidade federal, e de conjugar os esforços e recursos da União, dos Estados, dos Municípios e das entidades privadas, especialmente na área de atenção as pessoas.

\section{[página 2]}

Além da firme disposição do Governo Federal em reorganizar e racionalizar o setor saúde,foram realizadas iniciativas específicas nesse sentido, tais como: a unificação das atividades de assistência médica, no âmbito da Previdência Social, através do INAMPS; a instituição do PLANASA, no campo do saneamento básico; a instituição da CEME, com o seu programa de assistência farmacêutica; a criação do Fundo de Apoio ao Desenvolvimento Social - FAS; o advento de programas de largo espectro social, como o PIASS e o PRONAN, e as sucessivas reestruturações do Ministério da Saúde, em busca de melhor produtividade, ao lado de numerosas outras iniciativas a nível do Congresso Nacional, dos Governos Federal, Estaduais e Municipais e de entidades privadas.

Não obstante os esforços referidos e o significativo volume de recursos, inclusive de natureza financeira, colocados à disposição do setor, os resultados alcançados ainda revelam-se insatisfatórios, em termos de cobertura de serviços e de redução da magnitude das doenças e danos de maior significado sócio-sanitário.

Exemplos marcantes dessa situação evidenciam-se nos seguintes pontos:

- a melhoria dos indicadores de mortalidade é lenta e não se distribui equitativamente entre as diversas regiões e estratos sociais;

- permanecem as altas incidências de doenças transmissíveis evitáveis ou redutíveis, enquanto aumenta a importância das doenças degenerativas e dos problemas decorrentes da intensificação da concentração populacional e da atividade econômica moderna, sobretudo pela deterioração do ambiente; 
- a mortalidade infantil continua elevada, mantendo-se o seu coeficiente em torno de 100 óbitos por mil nascidos vivos, com diferenças regionais ainda expressivas;

- a periferia das grandes cidades e as pequenas localidades rurais continuam à margem dos benefícios representados pelos serviços de abastecimento de água e de esgoto sanitário;

\section{[página 3]}

Os recursos e serviços disponíveis para a atenção direta às pessoas apresentam-se extremamente concentrados, com níveis de complexidade e sofisticação em grande parte inadequados às necessidades básicas de saúde da população em geral e à estrutura nosológica prevalente. Paralelamente, constata-se significativa ociosidade da capacidade instalada do setor público.

As deficiências de desempenho e os insuficientes resultados obtidos pelo setor saúde, malgrado o significativo esforço empreendido pelo governo, decorrem fundamentalmente da multiplicidade de instituições atuantes e de sua persistente descoordenação, ambos os fatores levando à superposição de ações, ao desperdício de recursos, à baixa produtividade e, finalmente, ao desprestígio social do setor

A oferta de serviços faz-se, caracteristicamente, com predomínio das ações de recuperação da saúde, concentradas nos níveis secundário e terciário de atendimento, em detrimento da integralização das ações praticadas em vários níveis e do fortalecimento do atendimento básico de saúde.

Em decorrência, acentua-se a tendência ao progressivo e incontrolável aumento de custos e gastos das ações desenvolvidas, tal como ocorre em outros países, inclusive mais desenvolvidos, que adotam modelo assistencial semelhante.

A viabilidade do modelo atual depende da remoção das distorções que atualmente apresenta, pois, persistindo essas, as exigências de recursos poderão onerar, a níveis insuportáveis, o custeio das ações de saúde, a menos que se prejudiquem outros direitos e benefícios sociais já conquistados pela população brasileira.

O Programa Nacional de Serviços Básicos de Saúde - PREVSAÚDE constitui a opção do Governo Brasileiro para reordenar de forma gradual e progressiva o modelo de prestação de serviços do setor, de modo a adequá-lo às necessidades prioritárias da população e aos meios disponíveis para o seu suporte.

\section{[página 4]}

Representa uma adaptação, à problemática brasileira, das recomendações formuladas na Conferência de ALMA-ATA, promovida pela Organização Mundial da Saúde, onde se consagrou o privilegiamento da atenção primária de saúde.

O PREVSAÚDE traduz uma tomada de posição consciente para a efetiva implementação do Sistema Nacional de Saúde; os seus serviços constituirão a base do Sistema e sua porta de entrada regular, no campo do atendimento básico à saúde das pessoas, desempenhando também o papel de instrumento racionalizador do acesso aos níveis secundário e terciário, 
onde, além dos serviços públicos incluídos no PREVSAÚDE situa-se a atuação do setor privado (gráfico 1).

[página não numerada]

\section{REPRESENTAÇĀO DO PREVSAÚDE} NO SISTEMA NACIONAL DE SAÚDE

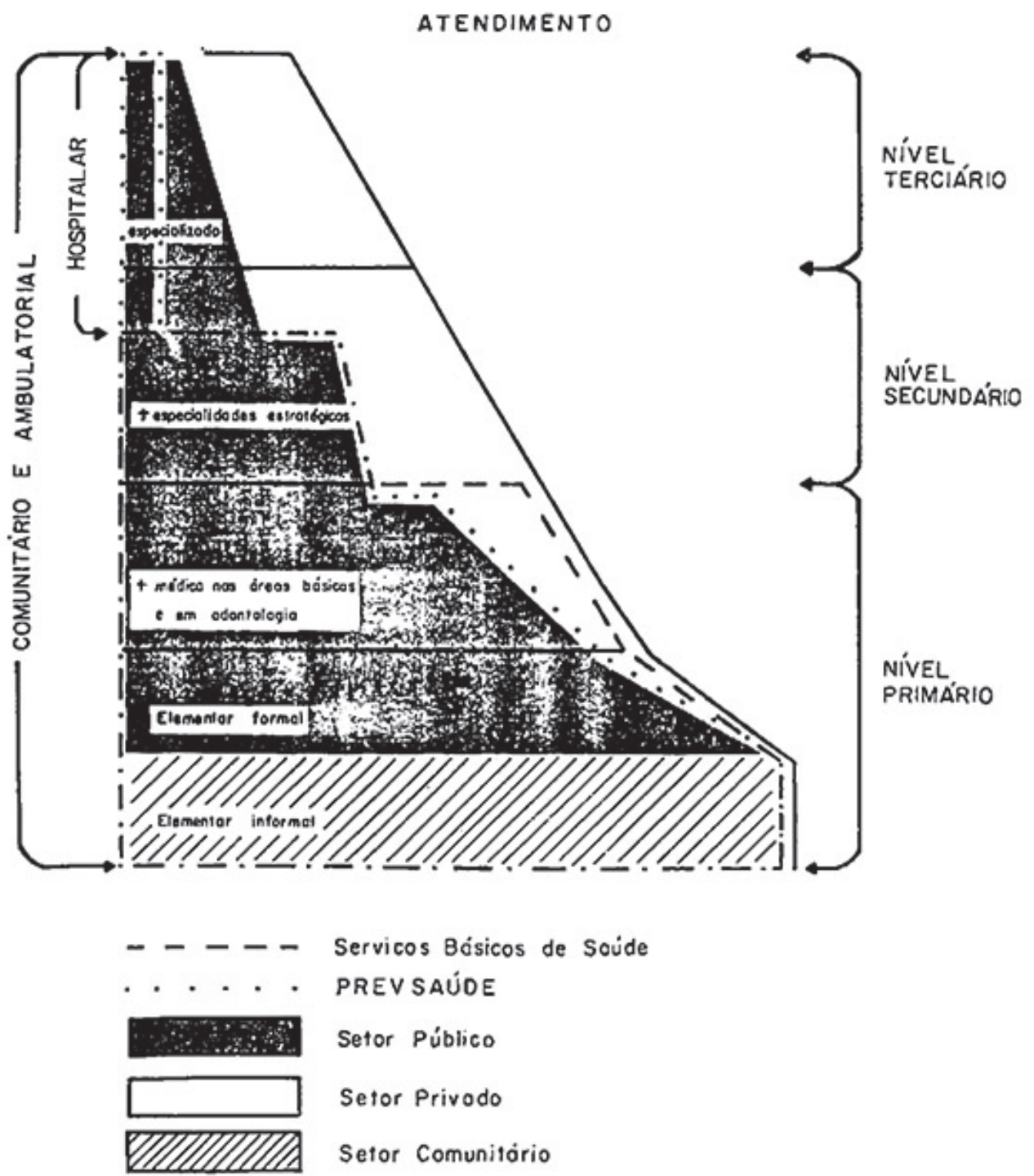




\section{[página não numerada]}

\section{ABRANGÊNCIA, OBJETIVOS E PRIORIDADES}

\section{[página 6]}

São seus objetivos principais:

a) Estender a cobertura por serviços básicos de saúde a toda a população;

b) Reordenar a atuação do setor público, promovendo a efetiva articulação das diversas instituições federais, estaduais e municipais;

c) Racionalizar a oferta de serviços do setor público, com vistas ao aumento da produtividade dos recursos disponíveis;

d) Promover a melhoria das condições sanitárias do ambiente, através da implantação de sistemas de abastecimento d'água, de destinação adequada dos dejetos, e de melhorias da habitação, particularmente nas áreas de maior prevalência de endemias, de grande densidade populacional.

\section{[página 7]}

\section{CONCEITO E ABRANGÊNCIA}

\section{[página 8]}

O PREVSAÚDE é constituído pelo conjunto integrado de serviços de natureza pública prestados às pessoas, às comunidades e à melhoria do ambiente, destinados à promoção da saúde, à prevenção das doenças, e à recuperação, com ênfase no tratamento das afecções e traumatismos mais comuns e reabilitação básica de suas consequências.

Seu campo de ação abrange todo o território nacional, estando seus serviços voltados ao atendimento da totalidade da população brasileira e envolvendo todas as instituições públicas que objetivam a prestação de serviços de saúde.

Os serviços pertencentes ao programa compreendem, prioritariamente, no âmbito da atenção às pessoas, os cuidados primários à saúde por profissionais generalistas, por pessoal auxiliar e por agentes da comunidade sob supervisão; o internamento em unidades mistas; o atendimento em serviços de urgência e/ou emergência, providos de leitos de observação; a atenção ambulatorial, especialmente a diferenciada nas quatro áreas básicas (clínica médica, clínica cirúrgica, gineco-obstetrícia, pediatria), em odontologia e em especialidades estratégicas definidas de acordo com a nosologia local prevalente.

Compreendem, ainda, as medidas simplificadas de saneamento básico, de melhoria da habitação popular e das condições ambientais gerais. 


\section{[página 9]}

\section{PRIORIDADES}

[página 10]

Mantida a abrangência nacional e a universalização do acesso aos serviços básicos, a implantação progressiva do Programa dar-se-á em conformidade com as seguintes prioridades:

a) atendimento de áreas carentes e grupos sociais mais desprotegidos, destacando-se, especialmente, as populações das periferias urbanas, das zonas rurais, das áreas de valorização econômica, de interesse da segurança nacional e destituídas de serviços primários de saúde;

b) controle de doenças transmissíveis, de outras enfermidades de ampla prevalência e tecnologia de resolução disponível, em especial as diarreias infecciosas, a cárie dentária, e a desnutrição;

c) atendimento dos grupos biologicamente expostos a maiores riscos, em especial crianças e mulheres em estado gestacional e de pós-parto;

d) desenvolvimento institucional e de recursos humanos, com vistas ao aperfeiçoamento das capacidades gerencial e operacional das instituições executoras e, também, da capacidade resolutiva dos serviços.

[página 11]

3. DIRETRIZES GERAIS

[página 12]

\subsection{REGIONALIZAÇÃO}

A organização dos serviços e o estabelecimento dos modelos de atendimento deverão estar orientados segundo os princípios de regionalização de serviços.

A ideia geratriz é a de que a rede de serviços básicos esteja organizada em níveis de complexidade crescente, e que estejam articulados funcionalmente.

\subsection{UNIVERSALIZAÇÃO DO ATENDIMENTO}

O acesso aos serviços básicos de saúde providos pelo PREVSAÚDE efetivar-se-á exclusivamente em função das necessidades da população, sem discriminação de qualquer ordem, assim como categoria social, nível de renda, vínculo previdenciário, etc.

Nesse sentido, estará prevista a universalização do atendimento à clientela em todos os serviços ambulatoriais e unidades mistas - federais, estaduais e municipais - participantes do Programa. 


\subsection{TECNOLOGIA APROPRIADA E PROCEDIMENTOS SIMPLIFICADOS}

Os recursos físicos e materiais pertencentes ao Programa, bem como os procedimentos diagnósticos e terapêuticos utilizados, devem corresponder ao nível de complexidade dos serviços, privilegiando a adoção de tecnologia simples, de modo a permitir o atendimento das necessidades de saúde da população ao menor custo possível.

\subsection{UTILIZAÇÃO INTENSIVA DE PROFISSIONAIS GENERALISTAS E PESSOAL AUXILIAR}

As equipes de saúde pertencentes ao Programa serão compostas por elementos cuja capacitação corresponda ao grau de complexidade das atividades desenvolvidas em cada nível de atendimento. Será dada ênfase à utilização de profissionais generalistas e de pessoal auxiliar de nível médio e elementar.

[página 13]

\subsection{REORGANIZAÇÃO ADMINISTRATIVA}

O desenvolvimento do PREVSAÚDE deverá proporcionar uma mudança de mentalidade na administração dos serviços de saúde, de tal forma a aliar a eficácia social dos serviços à máxima eficiência possível no uso dos recursos, mantendo-se um bom nível de qualidade do atendimento:

São componentes deste processo:

a) Integração Interinstitucional

A reorganização da oferta de serviços implica no desenvolvimento de um processo de integração das instituições pertencentes ao Programa, a partir de sua coordenação funcional; com isso, racionalizando a utilização e distribuição dos recursos e eliminando, progressivamente, a dualidade de ações e superposição de esforços.

b) Descentralização

Visando uma maior adequação dos serviços às necessidades de saúde, o processo de planejamento e execução deve ser descentralizado, de modo a permitir a participação da comunidade beneficiada e dos elementos envolvidos nos vários níveis de atenção.

\subsection{MÁXIMA PRODUTIVIDADE DOS SERVIÇOS}

A organização das atividades, a distribuição e a utilização dos recursos do Programa, serão orientadas para a obtenção de um nível de produtividade que possibilite elevada cobertura populacional. Entende-se por cobertura não apenas a simples proporção numérica entre população atendida e população geral, mas o resultado de uma oferta eficaz e sistematizada dos serviços que satisfaçam as suas necessidades essenciais, e que estejam dispostos em locais acessíveis e em forma por ela aceitável. 


\section{[página 14]}

\subsection{INTEGRALIZAÇÃO DAS AÇÕES DE SAÚDE}

A compreensão global do homem em suas dimensões biológica, psíquica e social concretiza-se, na prática dos serviços de saúde, através da prestação de ações integrais de saúde. Entende-se por ações integrais de saúde o conjunto articulado das medidas prestadas de promoção, proteção, recuperação e reabilitação.

\subsection{PARTICIPAÇÃO COMUNITÁRIA}

Ao nível do setor saúde, uma maior aderência dos serviços às necessidades da população é garantida na medida em que todo o potencial dos próprios beneficiários seja absorvido através de uma efetiva participação comunitária. O processo decisório referente às ações desenvolvidas pelo Programa deve ser orientado de modo a permitir a influência da comunidade no planejamento, execução e controle dos serviços que lhe são prestados, através de suas lideranças e formas organizativas próprias.

A participação da comunidade referentemente às ações de saúde locais será canalizada através das entidades representativas da população e estimulada por mecanismos de informação e divulgação de conhecimentos sobre saúde.

\subsection{ARTICULAÇÃO INTRA-SISTÊMICA}

A rede básica, entrada regular do sistema, se articulará com os níveis mais complexos, de modo a possibilitar o acesso, a esses serviços, a todos que efetivamente deles necessitem.

$$
\text { [página 15] }
$$

\section{CARACTERIZAÇÃO DO MODELO DE PRESTAÇÃO DE SERVIÇOS}

\section{[página 16]}

\subsection{ORGANIZAÇÃO DA REDE DE SERVIÇOS BÁSICOS}

O modelo assistencial proposto está estruturado em níveis de atenção articulados entre si, desde o elementar até o especializado, incorporando os níveis secundário e terciário ambulatoriais de atendimento do Setor Público. As unidades de saúde de cada nível deverão ter perfis funcionais e de recursos suficientes para a completa resolução dos problemas pertinentes a esse nível; cada unidade dentro de seu grau de complexidade deverá assumir a responsabilidade de atendimento integral de uma área e de uma população determinada, recebendo apoio dos níveis mais complexos e prestando-o aos de menor complexidade, em seu âmbito de atuação. Promover-se-á também a adscrição de clientela às respectivas unidades.

As unidades deverão estar distribuídas segundo modelo que atenda aos princípios de regionalização de serviços, dentre os quais pode-se destacar: 


\section{a) Suficiência}

A região sanitária deve conter, dentro de seus limites, os serviços necessários à atenção das necessidades básicas de saúde da população residente.

b) Diferenciação

A natureza, a dimensão e a complexidade dos serviços correspondem às características das necessidades a cuja atenção se destina.

c) Hierarquização

Os serviços estão relacionados entre si, em função da complexidade do atendimento, estabelecendo-se uma hierarquia do ponto de vista técnico-funcional, de modo a preservar a unidade do sistema que os integra. Os mecanismos de referência dos níveis de menor para os de maior complexidade devem ser estabelecidos de modo a garantir o acesso de toda a população ao atendimento de que necessita.

\section{[página 17]}

\section{d) Integração}

A regionalização dos serviços de saúde implica a integração das atividades e instituições por eles responsáveis, pelo menos em termos de coordenação funcional, não apenas no interior do próprio setor saúde, mas também nas relações que se estabelecem com os demais setores da vida social e econômica da região.

e) Descentralização e Desconcentração

A regionalização dos serviços de saúde deve compreender a desconcentração de atividades e funções administrativas e a descentralização do processo de tomada de decisão.

f) Flexibilidade

A regionalização dos serviços de saúde deve contemplar mecanismos que permitam sua adequação permanente à evolução das condições de saúde e socioeconômicas da região.

\subsubsection{NÍVEIS DE ATENÇÃO}

O primeiro nível de atendimento caracteriza-se pelo fato de permitir o acesso direto, constituindo-se em porta de entrada regular do sistema. Compreende a atenção elementar e a atenção primária diferenciada, incluindo, segundo as disponibilidades locais de pessoal, desde a participação de médicos generalistas prestando atendimentos nas quatro áreas básicas, e odontólogos, até atendentes e agentes comunitários devidamente orientados e supervisionados. A capacidade resolutiva aí é estimada em cerca de $80 \%$ em função de mecanismos que possam assegurá-la, tais como: adscrição de clientela; fiscalização dos serviços pela comunidade; estabelecimento de sistemas comuns de apoio, especialmente supervisão e controle; instituição de Plano de Cargos e Salários e educação continuada; utilização efetiva do pessoal de enfermagem nas atividades de capacitação, supervisão e prestação direta de serviços. 


\section{[página 18]}

O atendimento básico de saúde compreende: a promoção da melhoria nutricional; provisão adequada de água e outras medidas de saneamento básico; atenção maternoinfantil; imunização contra as principais doenças infecciosas, prevenção e controle de doenças endêmicas; odontologia social; educação no tocante a problemas prevalentes de saúde e aos métodos para sua prevenção e controle; tratamento apropriado de doenças e lesões comuns.

Nos níveis secundário e terciário ambulatorial desenvolvem-se atividades de apoio, cujo acesso fica condicionado à referência do nível primário, exceto nos casos de riscos que necessitam atenção diferenciada imediata.

As formas de organização dos níveis de atenção das unidades assistenciais em uma rede de serviços, composta segundo os princípios de regionalização, devem estar adequadas às características regionais e locais.

Como orientação geral para o estabelecimento dos modelos de atendimento, deve-se considerar:

a) o escalonamento em níveis de complexidade;

b) as condições especiais de atendimento médico nas cidades, requerendo maior complexidade em função da nosologia prevalente e da cultura assistencial preexistente;

c) que a orientação da demanda, com vistas a sua vinculação a uma determinada unidade, deve levar em conta o desempenho e a capacidade operativa da rede de unidades, de modo a assegurar o adequado atendimento;

d) as características de dispersão/concentração da população, as vias de acesso em uma dada região e a capacidade resolutiva dos níveis de referência.

$$
\text { [página 19] }
$$

\subsubsection{TIPOS DE UNIDADE}

A estrutura da rede assistencial do PREVSAÚDE é composta por unidades produtoras de serviços cujo porte, perfis funcionais e de recursos humanos e equipamentos variarão em função da área de cobertura e dos níveis de atenção a que se destinam.

Na definição dos vários tipos de unidade que integram a rede do PREVSAÚDE, deve-se buscar caracterizar um módulo mínimo de atividades e recursos para cada uma delas. As unidades poderão compreender um ou mais módulos, em função da cobertura populacional que devem prover.

a) Unidade Elementar ou Posto de Saúde

É a unidade sanitária mais simples, operada por pessoal auxiliar especialmente treinado para execução de ações básicas de saúde e supervisionado de forma sistematizada. Apoia o sistema informal (agente de comunidade), em áreas de população dispersa ou de pequenos núcleos. 
b) Unidade Ambulatorial (Centro de Saúde)

Tem como característica comum o atendimento médico permanente, variando sua complexidade e dimensões em função da magnitude da população a que serve, podendo chegar até o atendimento de urgência e/ou emergência e de nível secundário.

c) Unidade Mista

Tem como característica comum o atendimento ambulatorial e com internação nas especialidades básicas.

\subsection{ELENCO DE ATIVIDADES}

\subsubsection{SEGUNDO TIPOS DE UNIDADES}

a) Unidades Elementares

Desenvolverão atividades voltadas para a atenção materno-infantil; alimentação e nutrição; tratamentos padronizados de lesões comuns; urgências; notificação de casos; imuniza-

\section{[página 20]}

ções; educação para a saúde; fornecimento de medicação de esquemas terapêuticos padronizados; visitação domiciliar; colheita de material para exames laboratoriais; acompanhamento de egressos de outros níveis e referência aos mais complexos; ação comunitária; controle do ambiente; e atividades administrativas. A partir dessas unidades serão desenvolvidas atividades de penetração em áreas de população dispersa, com participação de agentes da comunidade e pessoal auxiliar do sistema de saúde. Essas categorias receberão treinamento, supervisão e apoio dos serviços de saúde e participarão basicamente, na execução de atividades como: campanhas, saneamento básico, melhorias de habitação, educação para a saúde, vigilância epidemiológica, etc. As ações desenvolvidas serão devidamente planejadas, controladas e avaliadas pelas unidades a que estiverem adscritas.

b) Unidades Ambulatoriais

Executarão, além das ações desenvolvidas nas unidades elementares, realizadas em maior grau de complexidade, as de vigilância epidemiológica, vigilância sanitária, controle de doenças transmissíveis, atenção ambulatorial generalista e diferenciada principalmente nas especialidades básicas, apoio diagnóstico laboratorial e radiológico, atendimento odontológico e de urgências e/ou emergências, de demanda espontânea e referida, bem como treinamento e supervisão de recursos humanos.

c) Unidades Mistas

Além das atividades já descritas nas unidades ambulatoriais, desenvolverão atenção integral nas especialidades estratégicas, e disporão de leitos para internação nas áreas de gineco-obstetrícia, pediatria, cirurgia e clínica médica. 
[página 21]

\subsubsection{SEGUNDO ÁREAS PROGRAMÁTICAS}

a) Controle de Endemias

Terá lugar destacado entre as prioridades do PREVSAÚDE, buscando-se:

- Apoiar a SUCAM nas ações de controle da doença de Chagas e Malária, mediante a ampliação dos recursos para a melhoria habitacional em áreas dessas endemias, a intensificação do combate aos vetores e vigilância epidemiológica.

- Desenvolver, sob coordenação da SUCAM, a expansão das ações de controle da esquistossomose, mediante destinação de recursos para abastecimento d'água e melhoria sanitária das habitações; intensificação do combate ao transmissor e o tratamento apropriado aos doentes.

- Intensificar ações para o adequado controle da hanseníase.

- Expandir as ações de controle da tuberculose e de outras pneumopatias de interesse sanitário, uniformizando métodos e esquemas de prevenção, diagnóstico e tratamento.

- Desenvolver ações destinadas ao controle de endemias de distribuição focal ou regional, como a filariose, leishmaniose, peste e tracoma.

- Cooperar na vigilância para fazer frente ao risco potencial de surto epidêmico da febre amarela no país, pela existência da doença sob forma silvestre e estimular a vacinação junto às populações que demandem as áreas endêmicas.

- Desenvolver esforços junto a OPAS/OMS para uma ação continental de combate ao Aedes aegypti.

- Instituir e estimular a extensão de medidas educativas para prevenção e tratamento das doenças de transmissão sexual e iniciar atividades sistemáticas de vigilância e controle.

[página 22]

b) Vigilância Epidemiológica

A vigilância epidemiológica constitui instrumento fundamental e pré-requisito para o estabelecimento de programas de controle de doenças. Consiste no conjunto de atividades capazes de proporcionar indicadores para acompanhar o comportamento epidemiológico de doenças nas comunidades, de forma a permitir a tomada de decisões oportunas e adequadas para a implementação de medidas de controle pertinentes.

São consideradas prioritárias as atividades de vigilância epidemiológica das doenças transmissíveis, destacando-se as evitáveis através da aplicação sistemática de agentes imunizantes.

Constituem requisitos para o desenvolvimento do sistema nacional de vigilância epidemiológica:

- estruturação técnica e administrativa de órgãos específicos, a nível do Ministério da Saúde e das Secretarias de Saúde; 
- coordenação interinstitucional visando a utilização ampla das fontes de notificação, ao melhor aproveitamento dos recursos tecnocientíficos disponíveis (laboratórios, instituições de pesquisa e ensino) e à maior eficiência das ações de controle;

- definição de mecanismos operacionais que garantam a notificação de doenças, o fluxo de informações e o apoio técnico-institucional necessário a cada componente do sistema;

- incremento da utilização da rede de serviços básicos de saúde, tanto para alimentação do sistema com dados básicos, como para a execução das ações de controle recomendadas.

c) Imunizações

Integrantes do núcleo mínimo de atenção primária, as imunizações constituem atividade prioritária dos serviços básicos, que deve ser desenvolvida de forma dinâmica e ativa, no sentido de atingir percentuais de cobertura que proporcionem segurança aos grupos populacionais susceptíveis, em re-

\section{[página 23]}

lação à poliomielite, sarampo, difteria, coqueluche, tétano e tuberculose. As unidades do PREVSAÚDE deverão estar mobilizadas para apoio às campanhas de vacinação em massa e de bloqueio de surtos.

d) Vigilância Sanitária

A proliferação de novos medicamentos, o crescente desenvolvimento tecnológico no setor de alimentação, e a introdução de novos hábitos, exigem a adoção de medidas visando proteger a população. Nesta área o PREVSAÚDE:

- fornecerá às atividades de vigilância o apoio técnico necessário, através da rede de laboratórios de saúde pública nele integrada;

- atuará descentralizadamente como agente do sistema de fiscalização, com participação dos órgãos estaduais e municipais respectivos;

- procurará cooperar estreitamente com os programas dirigidos ao "meio ambiente", especialmente o sistema coordenado pela SEMA/MINTER, participando das atividades de interesse da saúde na conservação ou recuperação do ambiente.

- atuará como agente de difusão de informações do sistema de vigilância tóxicofarmacológica.

e) Alimentação e Nutrição

As ações nesta área, visando as populações mais carentes, incluem atividades coordenadas e intersetoriais, contemplando as áreas de produção, comercialização e distribuição, suplementação e correção específica de deficiências nutricionais, recursos humanos, pesquisa e desenvolvimento tecnológico, componentes do Programa Nacional de Alimentação e Nutrição - PRONAN. O PREVSAÚDE deverá integrar-se a esse esforço particularmente através da distribuição de alimentos básicos, em caráter transitório e emergencial, aos grupos populacionais mais expostos ao risco de carências e em regiões 
de maior densidade de pobreza, além do desenvolvimento de atividades educacionais e de promoção especificas.

$$
\text { [página 24] }
$$

\section{f) Apoio Diagnóstico}

O PREVSAÚDE desenvolverá, através de rede de laboratórios, o atendimento à demanda de exames gerada pelos serviços básicos de saúde, no que se refere a análises clínicas para o atendimento às pessoas, estudos epidemiológicos, vigilância sanitária e controle ambiental.

g) Odontologia

Com o objetivo de expandir a atenção odontológica e reduzir a incidência dos problemas de maior prevalência, a política de saúde bucal está estrategicamente fundamentada na generalização de um núcleo mínimo de serviços, incorporando de maneira gradativa, cuidados mais complexos.

Constituem diretrizes de subprograma de odontologia:

- prioridade maior à prevenção da cárie dental; ao tratamento do grupo etário de 06 a 14 anos; aos grupos de baixa renda e às áreas economicamente mais carentes;

- máxima simplificação de insumos, traduzida na utilização de equipamentos e materiais de baixa complexidade tecnológica, custo mínimo e adequado padrão qualitativo;

- utilização de recursos humanos de quatro tipos:

a) Cirurgião-dentista;

b) Técnico de Higiene Dental, com funções expandidas;

c) Auxiliar de Consultório Dentário, com funções de apoio;

d) Atendente (auxiliar de saúde geral com atribuições de cuidados elementares em odontologia);

$$
\text { [página 25] }
$$

- regionalização da atenção, baseada na maior amplitude de serviços considerados essenciais e na diferenciação por áreas, partindo da periferia urbana e da zona rural até os centros populacionais mais densos.

A atenção odontológica no PREVSAÚDE estará estruturada em seis blocos de atividades:

- Prevenção Maciça, com ênfase na fluoretação da água de abastecimento público em cidades com mais de cinco mil habitantes que dispuserem de estação de tratamento;

- Cuidados Elementares, através de atenção mínima executada por pessoal local polivalente, disponível em todas as localidades;

- Atividades de Apoio, a cargo de unidades com recursos humanos diferenciados (centros de saúde e unidades mistas, etc.), que acrescentam as suas funções de atendimento à demanda, a supervisão do nível elementar e a consulta às pessoas referidas por Atendentes; 
- Atenção ao Escolar do $1^{\circ}$ Grau, pelo atendimento de alunos matriculados em escolas públicas via "sistema incremental";

- Referência para Casos Complexos, via racionalização dos serviços existentes, nas Universidades e Unidades mais diferenciadas, visando a cobertura de pessoas referidas pelos níveis anteriores sob critérios sociais;

- Oferta de Próteses pela expansão de serviços custeados pelos usuários, a preços equivalentes aos gastos de produção.

h) Saúde Escolar

Embora na faixa etária correspondente aos alunos de $1^{\circ} \mathrm{Grau}$ a mortalidade proporcional seja baixa, esse grupo apresenta

\section{[página 26]}

características que justificam ações de saúde específicas. Os problemas oftalmológicos, auditivos e odontológicos, que comprometem de maneira significativa o rendimento escolar, serão contemplados de maneira especial no PREVSAÚDE, exigindo atenção a partir da escola através de ações baseadas na simplificação e na possibilidade de extensa cobertura.

A assistência à saúde, a nível da escola, enfatiza aquelas ações que podem ser desenvolvidas pelos professores e/ou agentes de saúde em articulação e com o apoio dos Centros de Saúde da área. Tais ações, de caráter permanente, privilegiam o trabalho promocional e preventivo e são suficientemente simples, de modo a não exigir pessoal especializado para sua execução.

As atividades de saúde escolar devem conferir prioridade às seguintes ações: exame antropométrico, notificação de doenças, visitação domiciliar, primeiros socorros, imunização, atendimento a problemas mais comuns (de acuidade visual e auditiva, comportamentais, etc.) e referência a níveis de maior complexidade, além da atenção odontológica que está referida no item anterior.

Quanto aos cuidados sobre o ambiente escolar, salienta-se os de saneamento básico (água, dejetos e controle de vetores), e ainda o controle das condições de iluminação, ventilação e do local de preparo de merenda.

Inclui-se também o aperfeiçoamento dos programas desenvolvidos pelo MEC, de alimentação escolar e de educação para a saúde, este último de forma integrada entre a escola e os serviços de saúde.

i) Atenção Materno-Infantil

O grupo materno-infantil (mulheres em idade fértil e crianças) corresponde a mais de $70 \%$ da população brasileira.

\section{[página 27]}

Sua grande dimensão e a vulnerabilidade das gestantes, puérperas e crianças menores de 5 anos, principalmente em áreas carentes e frente as influências do meio, dão alta prioridade à assistência ao grupo, nos serviços básicos de saúde. 
Embora todas as medidas de saúde coletiva desenvolvidas pelos serviços básicos tenham repercussões sobre a saúde materno-infantil, as mulheres em idade fértil e as crianças necessitam de cuidados especiais, dadas as exigências da reprodução e do crescimento e desenvolvimento.

O elenco básico de atividades prioritárias contempla todas as fases do desenvolvimento do grupo materno-infantil, possibilitando:

- no pré-natal, o acompanhamento sistemático, com vistas à detecção precoce e assistência ao alto risco, a patologias prevalentes, ao câncer ginecológico e da mama e às doenças sexualmente transmitidas; à promoção da nutrição e da lactância materna; à vacinação antitetânica; à educação para saúde;

- no parto e para o recém-nascido, a assistência adequada aos partos de baixo e alto risco e a atenção ao recém-nascido;

- no puerpério, o exame gineco-obstétrico, o tratamento de doenças prevalentes e educação sobre puericultura básica e planejamento da família;

- para a criança menor de um ano, a supervisão periódica do crescimento e desenvolvimento; a promoção da alimentação materna; a prevenção e tratamento das diarreias, desidratação e desnutrição; e o desenvolvimento intensivo das imunizações;

- para o pré-escolar (1-4 anos), a supervisão do crescimento e desenvolvimento, assistência alimentar e nutricional, a prevenção e tratamento de diarreias e a continuidade das imunizações;

[página 28]

- nos períodos pré-concepcional e intergestacional, a atenção integral à família e à própria mulher, contemplando as atividades relativas ao processo de reprodução humana, dirigidas à regulação da fecundidade e ao tratamento da infertilidade. A atenção desenvolvida buscará sempre contribuir para que a mulher ou o casal possam, de modo consciente, e responsável, planejar os filhos que desejem, sem interferência ou indução de qualquer espécie e sem consequências negativas para a saúde. O exercício desse direito será assegurado, dentro do princípio superior e indeclinável de respeito absoluto à vida e às convicções éticas e culturais de cada casal e de cada mulher.

Todos os cuidados médicos devem ser dirigidos para proteger a vida da mulher e do concepto.

As atividades neste período compreendem:

- informação biopsicossocial sobre reprodução humana;

- conhecimento e estímulo da responsabilidade na assistência adequada aos filhos;

- estruturação sócio-jurídica da família e proteção econômica e trabalhista a seus membros;

- informação ampla sobre métodos naturais de regulação da fecundidade, adotando-se procedimentos de inocuidade comprovada, para aumento de sua eficácia; 
- informação seletiva sobre métodos artificiais de regulação da fecundidade, destacando seus perigos e contraindicações, no esforço para proteção da saúde dos que os utilizam;

- provisão de ações de controle da fecundidade em caráter individual, nos casos de indicação médica, segundo demanda e subordinada à vontade expressa do indivíduo, com métodos eficazes, eticamente aceitos;

- tratamento da infertilidade.

[página 29]

j) Assistência Médica

O programa contemplará ações de assistência médica individualizada, a nível ambulatorial e de unidades mistas, considerada a demanda espontânea e por referência aos serviços com ênfase nas quatro áreas básicas: tocoginecologia, pediatria, clínica médica e clínica cirúrgica. O desenvolvimento da assistência médica no PREVSAÚDE deverá objetivar, sistemática e prioritariamente, a resolução dos problemas de maior incidência e prevalência, contribuindo para a melhoria da condição de vida da comunidade.

k) Abastecimento d'Água e Destino dos Dejetos

Atuando-se em sintonia com o Ministério do Interior, objetiva-se nessa área:

- Em zonas urbanas de médio e grande porte:

- estimular a extensão da rede de abastecimento de água nas áreas mais carentes, propiciando o acesso das populações marginalizadas dos sistemas atuais a esses serviços;

. estimular a instalação de sistemas locais e independentes, com torneiras públicas, naquelas áreas periféricas urbanas onde não exista previsão de extensão da rede a curto ou médio prazo;

- promover a implantação de soluções simplificadas para a remoção de dejetos;

. orientar o descarte sanitário do lixo domiciliar;

- Em zonas rurais e pequenas comunidades:

- promover a implantação de soluções simplificadas e de baixo custo de instalação e manutenção para o abastecimento d'água e destino de dejetos;

[página 30]

. estimular a participação das prefeituras e comunidades, em todas as fases do projeto, como garantia para o funcionamento adequado dos serviços a serem implantados, asseguradas a supervisão e o apoio através de sistema de manutenção estadual, com base regional.

Abrangência e prioridades da área:

A população-alvo do Programa é constituída pelos grupos de baixa renda das cidades e os residentes em povoados e vilas, não servidos por sistemas de abastecimento d'água 
ou sem soluções adequadas para o destino dos dejetos. A atuação do PREVSAÚDE, com relação às atividades de saneamento básico, estende-se a todo o território nacional, tendo como prioridades toda a região Nordeste e as áreas de maior densidade de pobreza das grandes Cidades e regiões Metropolitanas. A atuação do Programa privilegiará na extensão do abastecimento d'água, as áreas onde predominam as doenças endêmicas. Em relação à destinação dos dejetos, as ações estarão concentradas nas áreas de prevalência da esquistossomose endêmica, com atuação apenas residual nas demais áreas.

Estratégia de atuação:

- Nas áreas urbanas, propõe-se a ação conjunta com as Companhias Estaduais de Saneamento e programas destinados à urbanização de favelas e erradicação da sub-habitação. A ação do Setor Saúde - via PREVSAÚDE - deve proporcionar uma composição de recursos que viabilize a extensão da rede de abastecimento de água, ou como segunda opção, a instalação de sistemas isolados de torneiras públicas, em áreas definidas como prioritárias pela Secretaria Estadual de Saúde e pela Companhia Estadual de Saneamento.

$$
\text { [página 31] }
$$

Serão estabelecidas tarifas sociais no sentido de garantirem, pelo menos, uma oferta mínima à população beneficiária. Em muitas áreas, onde a taxa de ligação de água constitua fator impeditivo para a extensão do benefício a novos consumidores, devem ser criados mecanismos facilitadores, como o financiamento das ligações domiciliares a custos acessíveis, ou mesmo a inclusão dessa despesa no custo de implantação do sistema e da rede pública de distribuição.

Estratégia de atuação em áreas rurais e pequenas comunidades

- Há áreas rurais e pequenas comunidades que, por suas características socioeconômicas, exigem soluções próprias e de custos significativamente inferiores às soluções adotadas rotineiramente. A atuação do PREVSAÚDE em pequenas comunidades tem como objetivo básico proporcionar a implantação de sistemas simplificados de abastecimento d'água e de soluções adequadas para o destino de dejetos, atuando complementarmente às companhias estaduais de saneamento.

1) Melhoria da Habitação Popular

Iniciativas governamentais recentes no campo da habitação popular, embora proponham o financiamento a custos subsidiados de obras singelas, não têm permitido o atendimento da população de muitas áreas, por impossibilidade de tomada de tais recursos pela maioria dos beneficiários.

Justifica-se, dessa forma, sob o ponto de vista sanitário, uma atuação complementar, à parte dos sistemas convencionais de financiamento, em áreas definidas por critérios socioeconômicos e epidemiológicos. Para essas áreas, propõe-se promover a melhoria de habitações, através de um sistema de baixo custo e fácil execução, que incorpore a contribuição dos próprios beneficiários. 
[página 32]

m) Saúde Ocupacional

Dar-se-á apoio às ações do Ministério do Trabalho no campo da saúde ocupacional objetivando a redução dos acidentes do trabalho, das enfermidades profissionais e das enfermidades comuns, relacionadas com o trabalho. Igualmente, incrementar-se-á o exame pré-admissional e o periódico de trabalhadores, e as ações de prevenção de doenças e de vigilância epidemiológica em trabalhadores mais expostos ao risco das doenças profissionais.

\subsection{DESENVOLVIMENTO DE RECURSOS HUMANOS}

O desenvolvimento de recursos humanos, no âmbito das instituições participantes, deverá obedecer a princípios comuns quanto aos aspectos de planejamento, capacitação, utilização e administração, objetivando valorizar o profissional de saúde e satisfazer as novas exigências criadas pelo Programa, no intento de atender às necessidades básicas da população.

\subsection{1. - PESSOAL DE NÍVEL ELEMENTAR}

O pessoal de nível elementar estará constituído basicamente por atendentes, auxiliares de serviços gerais e agentes da comunidade, recrutados e selecionados ou, em relação aos últimos, identificados na própria sede de serviços. Dos atendentes, exigir-se-á a capacidade mínima para absorver conhecimentos que os possibilitem a prestar, nos postos de saúde, certos cuidados primários, bem como para auxiliar o trabalho de outros profissionais de maior qualificação, nos centros de saúde, ambulatórios e hospitais. Sua formação dar-se-á mediante a integração ensino/serviço, em cursos descentralizados, com a utilização de instrutores/supervisores de nível superior e médio. O núcleo inicial de sua capacitação incluirá os cuidados essenciais às pessoas, medidas de preservação da higiene do meio e ações dirigidas

\section{[página 33]}

à comunidade.

\subsubsection{PESSOAL DE NÍVEL MÉDIO}

O pessoal de nível médio estará composto por profissionais que exerçam tarefas de determinada complexidade nas áreas de serviços finais (enfermagem, saneamento, odontologia, etc.), serviços de apoio diagnóstico e terapêutico (laboratório, radiologia, hemoterapia, farmácia, etc.) e serviços de apoio administrativo (administração geral, documentação médica e estatística, contabilidade, etc.).

Para as necessidades do Programa, tanto se recorrerá ao recrutamento de pessoas previamente habilitadas pelo ensino regular e supletivo de $2^{\circ}$ grau (habilitação de técnico e auxiliar), como também preparar-se-á certo contingente de força de trabalho no próprio serviço, exigindo-se, neste caso, escolaridade mínima de $1^{\circ}$ grau.

\subsubsection{PESSOAL DE NÍVEL SUPERIOR}

$\mathrm{Na}$ rede de serviços básicos, todos os profissionais de nível superior dedicados à prestação de serviços às pessoas e a ações sobre o meio devem ter atuação polivalente 
em sua área de formação. O profissional polivalente de atendimento médico é o médico generalista. Entende-se por médico generalista aquele que, atuando apenas apoiado numa equipe de auxiliares, está capacitado a resolver a maioria dos casos pertinentes às áreas de clínica médica, clínica cirúrgica, pediatria e tocoginecologia, realizando, também, pequenas cirurgias e desenvolvendo atividades de prevenção das doenças e promoção da saúde.

$$
\text { [página 34] }
$$

Além do médico generalista, o Programa contará, a nível de serviços básicos, com médicos exercendo funções diferenciadas nas quatro áreas básicas e, nos demais níveis, com os especialistas necessários.

Ainda compondo a equipe de saúde, o Programa utilizará todos os outros profissionais necessários ao seu desenvolvimento, de acordo com as necessidades identificadas nas programações.

\subsubsection{ADMINISTRAÇÃO DE PESSOAL}

Fator essencial e condição básica principal para a realização das atividades de saúde, os recursos humanos serão objeto de atenção prioritária e integrada, quanto aos aspectos de sua administração.

A administração de pessoal no PREVSAÚDE será efetuada tendo por base o estabelecimento de Planos de Cargos e Salários (PCS) estaduais, obedecidos princípios e diretrizes gerais de abrangência nacional.

O estabelecimento desses Planos tem os seguintes objetivos:

- compatibilizar a política de pessoal do Programa, envolvendo todos os recursos humanos das diferentes regiões e instituições participantes;

- permitir a movimentação de pessoal intra e interinstituições componentes do Programa, dentro de cada unidade federada, observados rigorosamente os interesses do serviço;

- estimular as categorias profissionais com deficiências de oferta no mercado de trabalho;

- adequar o desempenho dos recursos humanos, face aos objetivos e diretrizes do Programa, através da definição:

\section{[página 35]}

. de perfis funcionais e atribuições para todas as categorias;

- de jornadas de trabalho compatíveis, privilegiando o regime de tempo integral; e dedicação exclusiva, especialmente para os cargos correspondentes a funções administrativas de direção, supervisão, auditoria e sistemas reguladores de fluxo de demanda;

- de critérios de ingresso (seleção mediante concurso público para todos os níveis) e de progressão (tempo de serviço, educação continuada e avaliação de desempenho) nas diversas carreiras do PCS; 
. de critérios para estabelecimento de salários, adicionais (assessoramento e chefia) e incentivos (estimulo à interiorização e atuação em áreas carentes), com vistas ao estabelecimento de uma política salarial adequada.

O PCS, em cada Estado, será administrado pelo órgão gestor do PREVSAÚDE, em consonância com as diretrizes gerais estabelecidas pela coordenação nacional.

O PCS será implantado gradativamente e organizado, em cada Estado, de modo a oferecer possibilidade de movimentação do pessoal entre instituições participantes do PREVSAÚDE e objetivará desenvolvimento profissional, com a valorização do mérito e do desempenho, em conformidade com a formação básica e a qualificação de seus ocupantes.

\subsubsection{SUPERVISÃO E EDUCAÇÃO CONTINUADA}

O Planejamento das ações de supervisão deve fazer parte das responsabilidades a serem assumidas pelos grupos inter-

\section{[página 36]}

institucionais de coordenação, nos níveis central e regional, tendo por base uma única regionalização e princípios comuns para todas as instituições participantes.

A nível regional, as ações de supervisão deverão constituir parte dos mecanismos integrados de apoio adotados pelas instituições envolvidas no Programa, utilizando profissionais independentemente de sua subordinação administrativa.

\subsection{SISTEMAS DE APOIO}

O desenvolvimento das atividades assistenciais de alcance individual e coletivo prestadas pelo PREVSAÚDE depende da implantação de sistemas de apoio adequados, entre os quais se destacam os relacionados com planejamento, supervisão, treinamento, abastecimento, manutenção, informação, avaliação e controle. Os organismos de administração regional deverão desempenhar papel preponderante na implantação e operação destes sistemas. Para tanto, torna-se imperativo o fortalecimento destas administrações regionais, bem como a alocação de recursos materiais, físicos e humanos necessários. Simultaneamente, serão desenvolvidos esforços de capacitação gerencial e operacional das instituições participantes.

O processo de planejamento, em todas as suas fases, deverá se desenvolver segundo as diretrizes básicas de participação comunitária e descentralização decisória. Esta concepção implica a inversão do processo tradicional de planejamento vertical por programas, cedendo lugar ao planejamento integrado, a partir do nível local.

O sistema de informação do PREVSAÚDE deverá oferecer subsídios para o planejamento e a programação, bem como apresentar, com a frequência desejada, as informações necessárias para que as comunidades e as equipes atuantes nos vários níveis do Programa disponham de condições para avaliar permanentemente as 
[página 37]

condições sanitárias da população e os sistemas de prestação de serviços. As informações deverão abranger dados organizacionais, operacionais e epidemiológicos. O fluxo regular de informações será mantido pela constituição de núcleos essenciais de dados, sistematizados e organizados, de acordo com os níveis de decisão do sistema de serviços. O sistema deverá permitir, quando necessário, a coleta de dados adicionais e mais detalhados, através de estudos específicos e pesquisas amostrais.

O sistema de controle estará particularmente voltado para o acompanhamento da capacidade resolutiva da rede de serviços básicos, em termos quantitativos e qualitativos. Parâmetros de desempenho serão estabelecidos em relação às variáveis básicas dos serviços, tais como coeficiente e composição da referência, composição de atividades, utilização de fatores e insumos de produção, rendimentos e custos. Esses parâmetros serão regularmente acompanhados e avaliados através do sistema de informação e da supervisão. Auditorias serão estabelecidas em forma seletiva, para verificação de desvios do cumprimento dos parâmetros previamente determinados, auxiliando, também, na revisão das práticas.

O sistema de suprimento deverá ter por objetivo o fornecimento regular de materiais de consumo, medicamentos, produtos biológicos, películas radiológicas, reagentes, peças de reposição, além da prestação de assistência técnica. O funcionamento do sistema será facilitado pela padronização de insumos e equipamentos, com prioridade para aqueles que empregam tecnologia desenvolvida e controlada no país, e adequada ao grau de complexidade das ações.

\subsection{ESTUDOS E PESQUISAS}

Deverá ser parte integrante das atividades do PREVSAÚDE uma programação de estudos e pesquisas que terá por objetivo apoiar e orientar o seu desenvolvimento, servindo como mecanismo permanente do aperfeiçoamento das práticas de saúde.

$$
\text { [página 38] }
$$

Além do desenvolvimento de pesquisas e estudos por grupos acadêmicos e pelos organismos normalizadores competentes, a integração desta atividade aos serviços servirá de estímulo para uma contínua reflexão sobre as práticas por eles desenvolvidas, contribuindo, desta forma, para seu aperfeiçoamento e para o desenvolvimento de uma mentalidade crítica e criativa.

Devem constituir campos prioritários de pesquisas, ou estudos:

- elaboração de planos diretores regionais, para expansão e coordenação da rede de unidades de prestação de serviços;

- desenvolvimento de modelos de Unidades de Serviços, buscando simplificação e eficiência;

- desenvolvimento de sistemas comuns de apoio ao funcionamento da rede básica, como planejamento, informação, treinamento, educação continuada, supervisão, avaliação, controle e abastecimento de insumos básicos, entre outros; 
- padronização de condutas profiláticas, diagnósticas e terapêuticas, adequadas à realidade nosológica e institucional;

- estudos epidemiológicos e socioeconômicos, visando melhor compreensão e dimensionamento da realidade de saúde local, regional e nacional;

- desenvolvimento de tecnologia de baixo custo e apropriada aos serviços básicos (técnicas, materiais e equipamentos);

- revisão e compatibilização de normas e legislação referentes ao Sistema Nacional de Saúde, visando a superação de bloqueios à implementação das novas diretrizes da política nacional de saúde.

[página 39]

\section{ESTRATÉGIA DE DESENVOLVIMENTO DO PROGRAMA}

\section{[página 40]}

\subsection{ASPECTOS PRIORITÁRIOS}

A estratégia do PREVSAÚDE considera a sua implantação progressiva, garantida a irreversibilidade das medidas de ação adotadas, bem como a flexibilidade da programação, de modo a permitir tanto eventuais reajustes como sua adaptação à heterogeneidade dos diversos contextos regionais e locais.

A implementação do PREVSAÚDE desenvolver-se-á segundo duas linhas distintas. A primeira diz respeito ao aproveitamento integral da capacidade pública, da reorganização e readaptação das unidades, e da homogeneização de seus procedimentos técnicoadministrativos. A segunda se refere à ampliação da capacidade instalada de serviços básicos do setor público, devidamente harmonizada por normas estabelecidas.

A abrangência nacional do Programa não significa sua implementação simultânea, com ímpeto uniforme, em todas as Unidades Federadas. A existência de demandas não atendidas, a inexistência de serviços, razões epidemiológicas e a potencialidade administrativa e operacional dos sistemas existentes, determinarão o ritmo de implementação do Programa em cada Estado.

Além da prioridade dada a expansão de serviços nas áreas do PIASS - Programa de Interiorização das Ações de Saúde e Saneamento -, a definição de microrregiões preferenciais para a implantação do PREVSAÚDE contemplará:

a) quanto ao saneamento básico e medidas de melhoria da habitação:

- áreas de forte incidência da doença de Chagas e da esquistossomose; periferias urbanas; pequenas comunidades e áreas especiais de valorização econômica e de interesse da segurança nacional;

- quanto à prestação de serviços básicos de saúde às pessoas; 
[página 41]

- regiões de importância epidemiológica;

- periferias de médias e grandes cidades, onde são mais agudos os problemas de atenção médico-social;

- zonas de maior densidade de pobreza e de inexistência de serviços;

- áreas onde existam pré-condições técnico-administrativas favoráveis, por parte das instituições componentes do programa;

- áreas especiais de valorização econômica e de interesse da segurança nacional.

Também será concedida prioridade ao desenvolvimento da capacidade operacional de Estados e Municípios dentro do processo de descentralização proposto e às iniciativas e atividades de organização e desenvolvimento da comunidade.

Em termos de pessoal aparecem, em destaque, o incentivo ao regime de tempo integral e dedicação exclusiva; a formulação de planos federais e estaduais de cargos e salários, para todas as categorias; adoção de política salarial apropriada, com estímulo: ao exercício em localidades carentes e ao desempenho de funções de direção de serviços, supervisão, educação continuada, auditoria e regulação de fluxo de demanda.

\subsection{RESPONSABILIDADES INSTITUCIONAIS}

A universalização do acesso aos serviços básicos de saúde e a melhoria das condições de saneamento requerem a integração de esforços das comunidades e das instituições participantes do PREVSAÚDE.

$\mathrm{Na}$ órbita federal, esses objetivos exigirão contribuição dos Ministérios que compõem o Conselho de Desenvolvimento Social, principalmente os da Saúde, da Previdência e Assistência Social, do Interior, da Educação e Cultura, do Trabalho, e da Secretaria de Planejamento da Presidência da República,

Aos Ministérios da Previdência e Assistência

$$
\text { [página 42] }
$$

Social e da Saúde caberão, a nível federal, as principais responsabilidades na condução e financiamento do PREVSAÚDE, e através dos diversos organismos de suas estruturas, no apoio técnico-administrativo aos Estados.

Órgãos dos dois Ministérios, como a SUCAM, o INAN, a FSESP, o INAMPS, a CEME, a FIOCRUZ, a LBA e a FPS, entre outros, adaptarão seus esquemas de trabalho, no que couber, às linhas de ação fixadas.

A SUCAM, mantendo suas funções executivas e de coordenação transferirá para as unidades federadas as atividades de combate às endemias de natureza focal, e de vigilância epidemiológica em áreas onde se tenha ultrapassado a fase de ataque a problemas como 
Malária, Doença de Chagas, Febre Amarela e Esquistossomose. Sob essa diretriz, a SUCAM assegurará suporte técnico-financeiro aos Estados, quando necessário.

A FSESP, por sua vez, desenvolverá sua ação executiva na prestação de serviços integrados de saúde, nas áreas de penetração ou colonização agrária, de valorização e desenvolvimento, estratégicas ou de segurança nacional. A experiência acumulada por essa instituição, no planejamento e administração de serviços de saúde e saneamento, em comunidades de pequeno e médio portes, será utilizada. A FSESP intensificará sua atuação no assessoramento técnico aos Estados na reorganização de seus serviços de saúde, capacitação de recursos humanos, vigilância epidemiológica, e, ainda, para o desenvolvimento de modelos de administração e planejamento de serviços integrados de saúde.

O INAMPS e a CEME apoiarão as estruturas estaduais, mediante:

- Articulação operacional das Superintendências Regionais do INAMPS com as Secretarias de Saúde, visando a integração programática e desenvolvimento harmônico do PREVSAÚDE;

- Suprimento adequado de medicamentos e produtos biológicos às instituições executoras do programa, através da CEME;

- Assessoramento técnico-administrativo.

[página 43]

Os serviços próprios ambulatoriais do INAMPS ajustar-se-ão às diretrizes do Programa. Com esse objetivo, as atividades dessas unidades deverão, sempre que indicado, ser redefinidas em função dos problemas de saúde e da disponibilidade e diversificação dos demais serviços oficiais na mesma área de influência.

A participação do Ministério da Educação e Cultura dar-se-á sobretudo no desenvolvimento de recursos humanos, preferencialmente em regime de integração docente-assistencial, e no desenvolvimento de atividades de saúde e alimentação do escolar. Com relação a estas, mesmo quando situadas no âmbito administrativo das Secretarias Estaduais de Educação, integrar-se-ão ao Programa. Desenvolver-se-á, em conjunto com o MEC, alteração nos currículos universitários, visando adequá-los à nova prática do Programa.

A extensão de cobertura por sistemas adequados de abastecimento d'água e destino de dejetos, a erradicação da sub-habitação rural e urbana e outras ações sobre o meio ambiente, constituem responsabilidades precípuas do Ministério do Interior, que, nas áreas de atuação prioritária do PREVSAÚDE, serão integradas às do Programa. A existência de programas específicos dirigidos aos campos acima mencionados, reserva ao sistema de saúde em geral, e ao PREVSAÚDE, em particular, um papel executivo complementar. Não obstante, constitui atribuição do sistema de saúde, compatibilizar a atuação desses programas, de modo a proporcionar-se um adequado atendimento aos problemas de saúde cuja solução dependa da melhoria do ambiente.

A ação complementar do PREVSAÚDE nessas áreas deverá ser claramente definida em cada Plano estadual, de forma a assegurar perfeita articulação com os programas do MINTER. 
[página 44]

O PREVSAÚDE, em cada Unidade Federada, definirá formas complementares de ação, abrangendo a execução de serviços de saneamento básico e de melhoria habitacional, em áreas estabelecidas de comum acordo com o MINTER, assumindo, parcialmente, encargos financeiros desses benefícios em áreas de baixa renda.

As Superintendências do Desenvolvimento Regional e demais entidades vinculadas ao MINTER prestarão assistência técnico-administrativa, aos Estados na implementação do PREVSAÚDE, em especial, no que diz respeito à articulação, de modo a assegurar a incorporação ao Programa dos componentes de saúde dos Projetos Especiais sob sua responsabilidade, inclusive a aplicação dos recursos específicos disponíveis, bem como na organização e capacitação gerencial das Secretarias de Saúde.

O MINTER ainda promoverá ações de sua Secretaria Especial do Meio Ambiente com vistas à programação de vigilância sanitária.

Em ação conjugada com o Ministério do Trabalho intensificar-se-ão atividades de saúde ocupacional.

Finalmente, na área federal, a SEPLAN - responsável pela Secretaria Executiva do Conselho de Desenvolvimento Social e pela assistência permanente à Presidência da República, na coordenação de assuntos que envolvem a participação de mais de um Ministério - acompanhará o desenvolvimento do PREVSAÚDE, submetendo suas análises periódicas sobre a evolução do Programa à apreciação do CDS, coordenará a mobilização de recursos externos, e assegurará a aplicação de recursos específicos dos Fundos e Programas Especiais sob sua coordenação, no desenvolvimento do PREVSAÚDE.

[página 45]

As Secretarias Estaduais de Saúde terão a responsabilidade de gerência operacional do PREVSAÚDE e da harmonização dos sistemas comuns de apoio, objetivando a integração programática.

Aos municípios - considerada a heterogeneidade de situações - caberão responsabilidades na administração dos serviços locais de saúde, a serem definidas nos respectivos Planos Estaduais do PREVSAÚDE.

Condições técnico-administrativas e financeiras insatisfatórias por parte de alguns governos estaduais e administrações municipais não deverão constituir fator impediente definitivo para o pleno exercício dessas competências. A remoção dessas dificuldades e a criação de condições adequadas ao processo de descentralização e à capacitação dos níveis local e regional inserem-se, com prioridade, no elenco de objetivos do PREVSAÚDE.

Serão estabelecidos mecanismos que definam os compromissos institucionais respectivos e assegurem seu cumprimento; destacam-se os cuidados para evitar a retração do aporte de recursos estaduais e locais, em função da alocação de recursos federais adicionais, e a necessidade de garantir-se a corresponsabilidade federal, no que se refere ao ônus assumido pelos estados e municípios, com a expansão dos serviços e seu desenvolvimento. 


\subsection{MECANISMOS DE INTEGRAÇÃO, COORDENAÇÃO E GERÊNCIA}

Do ponto de vista institucional, a proposta do PREVSAÚDE ajusta-se à multiplicidade do sistema político-administrativo brasileiro. A viabilidade do modelo que se propõe, com vistas a obter a coordenação interinstitucional, será assegurada mediante:

- efetivo funcionamento de mecanismo interministerial, a nível federal, de coordenação geral do Programa;

$$
\text { [página 46] }
$$

- definição de instrumento de alocação de recursos que assegure a continuidade de repasse dos recursos federais e estaduais necessários à implantação e operação do PREVSAÚDE, no período de sua execução;

- implantação e efetivo funcionamento de mecanismo interinstitucional de coordenação do Programa, a nível das Unidades Federadas;

- definição de instrumento de integração programática - Plano Estadual do PREVSAÚDE;

- estabelecimento de instrumento flexível de administração dos recursos, a nível de Unidade Federada; e

- unidade de direção, pela Secretaria Estadual de Saúde, dos sistemas comuns de apoio (planejamento, treinamento, educação continuada, informação, supervisão, abastecimento de insumos críticos e plano de cargos e salários).

No nível federal, os Ministérios da Saúde e da Previdência e Assistência Social, através de mecanismo comum - Comissão Interministerial de Planejamento e Coordenação/CIPLAN -, nucleiam a articulação específica com os demais Ministérios e conduzem o Programa, sob a direção dos Ministros de Estado respectivos. A atividade de coordenação nacional do PREVSAÚDE, desenvolvida pela CIPLAN será realizada por grupo interministerial específico composto de representantes dos Ministérios envolvidos no Programa. A CIPLAN disporá de Secretaria Técnica, composta insterinstitucionalmente, com vistas ao desempenho de sua competência, devidamente apoiada pelos órgãos das estruturas dos Ministérios referidos.

No nível estadual, Comissão Interinstitucional de Planejamento e Coordenação (CIPE) integrada no mínimo pelos dirigentes, a esse nível, do Ministério da Saúde, do INAMPS e da Secretaria Estadual de Saúde, presidida pelo titular desta última, além de um representante da área de planejamento de cada

[página 47]

órgão - exerce a coordenação do Programa e detém a responsabilidade da articulação com outras Secretarias de Estado, seus órgãos vinculados, bem como outros órgãos participantes da execução do PREVSAÚDE. A CIPE será assessorada, no desempenho de sua competência, por Assessoria Técnica de composição paritária, representativa dos três órgãos, encarregada da avaliação de desempenho técnico-financeiro do PREVSAÚDE. Essa assessoria promoverá sistematicamente a unidade de direção do PREVSAÚDE, atuando seus membros em regime de dedicação exclusiva. 
No nível de região de saúde da Unidade Federada, situam-se as funções principais de supervisão e apoio técnico-operacional, devendo-se, para isso, dispor de mecanismos apropriados que possibilitem homogeneizar a ação interinstitucional nas respectivas áreas de abrangência.

No nível municipal, onde se exercitam as atividades fins do Programa, as organizações representativas participarão na definição das ações propostas para as comunidades a que pertencem. O nível de atuação dos Municípios, considerada a heterogeneidade de situações, ficará estabelecido nos Planos Estaduais do PREVSAÚDE.

A gerência operacional do PREVSAÚDE, a nível das Unidades Federadas, caberá à Secretaria Estadual de Saúde, encarregada da implementação, acompanhamento e controle do Programa, a qual deverá ser apoiada, para o exercício de suas responsabilidades, pelas estruturas técnico-administrativas dos órgãos do MPAS e do MS, na forma estabelecida no mecanismo tripartite - MPAS/MS/Governos Estaduais - a ser definido para implementação do Programa.

A administração dos serviços próprios federais pertencentes ao INAMPS e FSESP será exercitada pelas próprias instituições, em harmonia com a gerência operacional do Programa.

A expansão e adequação da rede do PREVSAÚDE terá um Plano Diretor, parte integrante dos Planos Estaduais, observados critérios de disponibilidade de recursos para investimentos e manutenção, de regionalização, de adequação de portes e perfis

$$
\text { [página 48] }
$$

funcionais, e os demais padrões e normas fixados em conjunto pelos Ministério da Saúde e da Previdência e Assistência Social, através da CIPLAN.

A construção ou ampliação de unidades de saúde serão regidas pelo definido no Art. $6^{\circ}$, e seus parágrafos, da Lei $n^{\circ} 6.229 / 75$, que dispõe sobre a organização do Sistema Nacional de Saúde.

Adotar-se-á o planejamento integrado de toda a rede, independentemente da vinculação institucional de suas unidades componentes, de modo a que possam ser estabelecidas coberturas específicas para cada serviço, bem como racionalizadas as relações de referência e contrarreferência e a adscrição de clientela.

Os sistemas comuns de apoio ao PREVSAÚDE - planejamento, informação, treinamento, educação continuada, supervisão, avaliação, controle e abastecimento de insumos críticos deverão enquadrar-se em fluxo único no âmbito de cada Unidade Federada, sob a coordenação da CIPE e direção da Secretaria Estadual de Saúde.

\subsubsection{ADMINISTRAÇÃO FINANCEIRA}

Os recursos financeiros destinados pelos Ministérios da Saúde e da Previdência e Assistência Social, e suas entidades, às Secretarias Estaduais de Saúde para o desenvolvimento do PREVSAÚDE, serão transferidos mediante convênio único tripartite e integrarão fundo 
de natureza contábil, juntamente com os recursos adicionados pelos Estados para esse fim. Os recursos totais necessários à viabilização dos investimentos e implantação dos planos de cargos e salários serão integrados ao fundo estadual.

A movimentação dos recursos far-se-á através de conta-convênio vinculada, abrindo-se subcontas específicas por fontes de financiamento.

Os recursos de outras instituições federais, diretamente transferidos para as Secretarias Estaduais de Saúde, serão administrados em acordo a disciplina específica estabelecida em convênio.

$$
\text { [página 49] }
$$

As dotações das entidades federais, participantes do PREVSAÚDE, destinadas ao custeio da operação dos serviços próprios, serão aplicadas diretamente, constando atividade específica em seus orçamentos. Em qualquer caso, a aplicação desses recursos será feita em estreita obediência ao Plano Estadual do PREVSAÚDE.

Os Ministérios da Saúde e da Previdência e Assistência Social exercerão, através de seus órgãos competentes, controle financeiro e auditoria, no que se refere a seus recursos transferidos.

\subsection{ARTICULAÇÃO COM OUTROS PROGRAMAS E INSTITUIÇÕES}

O Programa de Interiorização de Ações de Saúde e Saneamento - PIASS, criado em 1976 para atender, na Região Nordeste, as localidades com menos de 20.000 habitantes e ampliado, em 1979, para as demais comunidades no país como um todo, observado o mesmo parâmetro populacional, estará integrado ao PREVSAÚDE.

Essa integração, fundamentada na identidade de propósitos dos dois Programas, na necessidade de somar esforços, e na conveniência de unificar o comando das ações, com vistas ao atendimento das necessidades da população no campo da Saúde, assegura a manutenção das prioridades de atuação fixadas no Decreto $\mathrm{n}^{\circ} 84.219$, de 14.11 .79 , que aprovou a ampliação dos serviços básicos de saúde e saneamento, através do PIASS, para o período de 1980-1985, passando a sua execução a ser regida pelas diretrizes do PREVSAÚDE

A existência, ao nível de cada estado o município, de outros empreendimentos com objetivos comuns, no todo ou em parte, com o PREVSAÚDE, implicará em soluções próprias, com vistas a sua integração ao Programa.

\section{[página 50]}

A articulação com o PLANASA no campo do saneamento, com o PLACAR e o PROMORAR na erradicação da sub-habitação rural e urbana, objetiva o atendimento de populações marginalizadas e privilegia áreas de maior prevalência de endemias. Serão implementados instrumentos específicos de articulação recíproca, com o MINTER, que definirão, em cada caso, áreas de atuação, competências institucionais, bem como as modalidades de ação que atendam as diretrizes do PREVSAÚDE.

As atividades de suplementação alimentar, objeto do Programa Nacional de Alimentação e Nutrição - PRONAN, executadas através do PNS, serão desenvolvidas na rede de serviços 
básicos. Os serviços de saúde apoiarão ainda o PRONAN no desenvolvimento de ações educativas e de promoção da produção e consumo de alimentos básicos. As atividades de alimentação do escolar, executadas pela CNAE, também integrantes do PRONAN, articular-seão com as ações de saúde escolar e com os serviços básicos, potencializando-se reciprocamente.

Iniciativas setoriais de evidente especificidade e importância no campo do desenvolvimento tecnológico e da produção de insumos farmacêuticos e agentes imunizantes; suprimento de sangue e hemoderivados, bem como do controle da qualidade de medicamentos e alimentos, consubstanciadas no PROFÁRMACO, PROIMUNO, PROSANGUE e PROCONTROLE, terão como balizamento as demandas geradas pela rede básica de prestação de serviços de saúde.

Igual preocupação estará presente na programação da Central de Medicamentos. A expansão dos recursos da CEME aparece como condição imprescindível para permitirlhe cumprir as responsabilidades de abastecimento de medicamentos, imunobiológicos e outros insumos essenciais.

[página 51]

6. METAS, CUSTOS E FINANCIAMENTO

\section{[página 52]}

A definição de metas, custos e de estrutura de financiamento do Programa está baseada em estimativas globais representativas das necessidades de recursos requeridos pelo PREVSAÚDE, segundo seus principais objetivos. Tais estimativas, no entanto, devem ser necessariamente ajustadas, anualmente, frente a cada fase de implementação do Programa, considerando-se como linha norteadora desses ajustes:

- as quantificações mais precisas, que reflitam as diferentes realidades e necessidades estabelecidas nos planos de trabalho de cada Unidade Federada;

- as avaliações e subsequentes revisões, realizadas regular e periodicamente, em função do grau de desempenho do Programa e do desenvolvimento da aplicação dos seus principiais instrumentos estratégicos: coordenação interinstitucional, fluxo e administração de recursos financeiros, plano de cargos e salários, etc.

- a materialização dos compromissos financeiros existentes.

As tabelas foram elaboradas no sentido de especificar as metas de atividades e de cobertura e os custos de investimento e operação. São apresentadas segundo as grandes regiões e subprogramas gerais, destacando-se os dados referentes ao ano inicial do Programa, 1981, e no final o total do período.

As metas e custos estabelecidos abrangem todos os serviços ambulatoriais e unidades mistas próprios do Ministério da Saúde, do Ministério da Previdência e Assistência Social 
- INAMPS -, e das Secretarias Estaduais de Saúde e Municípios bem como atividades de apoio para o desenvolvimento do PREVSAÚDE (capacitação de recursos humanos, desenvolvimento institucional, pesquisa e desenvolvimento

[página 53]

tecnológico e o suprimento de medicamentos e vacinas pela CEME).

No campo do saneamento e da melhoria de habitação incluem-se as metas e custos referentes às atividades que se propõe sejam realizadas diretamente pelo MINTER, além das desenvolvidas pelo Programa.

Estão previstos, ainda, recursos originados do Ministério da Educação e Cultura para as ações referentes à saúde escolar.

O objetivo da cobertura de toda a população com serviços básicos, através da rede pública, exigirá ampliação da capacidade instalada atual:

a) recuperando e implementando plenamente os recursos físicos existentes;

b) implantando novas unidades assistenciais;

c) desenvolvendo o saneamento básico e a melhoria da habitação.

\subsection{METAS}

\subsubsection{SERVIÇOS BÁSICOS DE ATENDIMENTO ÀS PESSOAS}

A meta global de cobertura por serviços básicos foi estabelecida a partir da atividade mais complexa de atenção considerada nuclear para este efeito: a consulta médica primária. Na consulta médica, assim concebida, estão incluídas todas as demais atividades de atendimento realizadas nos módulos assistenciais (exceto odontologia, para a qual foram estabelecidas metas próprias) e as atividades complementares constantes dos perfis funcionais desses módulos.

[página 54]

Estabeleceu-se a meta de concentração média por pessoa de 1,9 consultas/ano, cobrindose $90 \%$ da população total e estimando-se a necessidade de consultas especializadas em $20 \%$ das consultas primárias e as urgências em $15 \%$. A capacidade de atendimento elementar foi fixada por cobertura médica populacional, por posto de saúde: 3.000 habitantes rurais, por posto; esse padrão, um tanto elevado, justifica-se pelas tendências à urbanização da população (inclusive com redução absoluta da população rural a longo prazo); à demanda de serviços mais complexos de atendimento médico; e pela participação esperada dos agentes da comunidade.

As metas principais podem resumir-se:

a) Expansão de Capacidade (TABELAS 1 e 2)

- implantação de 7700 Postos de Saúde;

- implantação de 16400 novos consultórios médicos;

- recuperação, para utilização plena, de 5600 consultórios médicos; 
- implantação de 3050 novos consultórios odontológicos e recuperação, para utilização plena, de 2390, incluindo os de atendimento escolar;

- implantação de 6000 leitos de Unidades Mistas;

- implantação de 1430 módulos de urgência/emergência.

b) Produção de Serviços (TABELAS 3, 4 e 5)

\section{[página 55]}

- 246 milhões de consultas medicas básicas, 49 milhões de consultas especializadas, elevando a 2,0 a concentração média de consultas médicas por pessoa;

- 37 milhões de atendimentos de urgência/emergência;

- 46 milhões de consultas odontológicas e atendimento integral de 10,6 milhões de escolares urbanos;

- 500 mil altas de internação em Unidades Mistas;

- 6 milhões de pessoas beneficiadas com suplementação alimentar;

- 25 milhões de crianças vacinadas contra Poliomielite, Sarampo, Coqueluche, Difteria, Tétano e Tuberculose;

- 19 milhões de gestantes serão vacinadas contra o Tétano.

- 12,5 milhões de pessoas contra a Febre Amarela.

Para tanto serão necessárias as seguintes quantidades de doses de vacina: Poliomielite 400 milhões; Sarampo - 80 milhões; Tríplice (DPT) - 105 milhões; BCG - 50 milhões; Toxoide Tetânico - 50 milhões; Febre Amarela - 43 milhões. Além destas serão necessárias vacinas de uso estratégico ou eventual: Antimeningocócica (estoque estratégico) - 18 milhões; Tifoide (estoque estratégico) - 6 milhões; Antirrábica Humana (aplicação em pessoas agredidas por animais) - 15 milhões, Antirrábica Canina - 50 milhões.

O total previsto das vacinas necessárias atinge cerca de 817 milhões de doses no período 1981-86.

\subsubsection{SANEAMENTO E HABITAÇÃO (Tabela 6)}

a) água potável para mais de 14,7 milhões de pessoas;

[página 56]

b) 1,33 milhões de domicílios servidos com esgoto sanitário;

c) melhorias em 310 mil habitações situadas em áreas endêmicas.

\subsubsection{RECURSOS HUMANOS (tabela 7)}

Propõe-se reciclar ou treinar, em todos os níveis: cerca de 308,5 mil funcionários de todas as categorias, inclusive 13.900 treinamentos de pós-graduação, em sentido amplo. Esse treinamento deverá abarcar, também, agentes da comunidade ligados à saúde. 


\subsection{CUSTOS}

\subsubsection{INVESTIMENTOS (tabelas 8, 9,10 e 16)}

Os investimentos totais no período 81/86 estão estimados em Cr\$ 220.6 bilhões, a preços de 1981, assim distribuídos: Serviços Básicos às Pessoas, Cr\$ 67.2 bilhões; Administração e Apoio, Cr\$ 38.7 bilhões (sendo, Cr\$ 16.5 bilhões em Desenvolvimento Institucional; Cr\$ 16.8 bilhões em Recursos Humanos; e Cr\$ 5.4 bilhões em Pesquisa e Desenvolvimento); Saneamento, Cr\$ 83.8 bilhões; e Habitação, Cr\$ 30.8 bilhões.

Os critérios para determinação dos custos procuram refletir os padrões técnicos oficiais ou propostos para os serviços de saúde; valores médios unitários de mercado para construção e equipamento de estabelecimentos, e valores de mercado para recursos humanos, saneamento e habitação.

A distribuição dos investimentos diretos corresponde ao cronograma de metas de implantação do Programa, objetivando:

a) realizar, em primeiro lugar, os investimentos com "períodos de projeto" menor, tais como os destinados à implementação da capacidade existente;

[página 57]

b) criar, desde logo, condições para o desenvolvimento do Programa (Desenvolvimento Institucional e de Recursos Humanos);

c) antecipar a implantação dos Centros de Saúde, em relação aos Postos de Saúde e leitos hospitalares (pelo apoio necessário à operação dos primeiros e pela prioridade do atendimento ambulatorial, sobretudo nas cidades);

d) reduzir os dispêndios em 1981, em função do tempo necessário às negociações de financiamento, e de implantação do Programa e preparação técnico-administrativa, dos agentes de gerência e execução; e para viabilização dos remanejamentos de recursos, bem como captação de fontes adicionais propostas.

\subsubsection{OPERAÇÃO (tabelas $12,13,14,15$ e 16)}

O custo total acumulado de operação do Programa será de ordem de Cr\$ 915.6 bilhões a preços de 1981, distribuídos segundo subprogramas gerais, na seguinte forma: serviços básicos às pessoas e ao ambiente, Cr\$ 824,3 bilhões; e administração e apoio (recursos humanos, desenvolvimento institucional e pesquisa e desenvolvimento tecnológico), Cr\$ 91.3 bilhões.

O custo total de operação do Programa, em 1981, está estimado em Cr\$ 81.6 bilhões e o de operação plena, em 1986, em Cr\$ 188.1 bilhões, a preços de 1981.

O incremento de custos pela expansão da capacidade se fará sentir, principalmente, a partir de 1982. 
Os critérios para determinação dos custos de operação foram os seguintes:

a) para os serviços básicos às pessoas, a partir dos custos de pessoal, calculados em função dos padrões adotados de lotação pa-

$$
\text { [página 58] }
$$

ra cada módulo, aos níveis salariais da administração federal (corrigidos, em alguns casos, na expectativa de implantação de carreiras). Admite-se que as despesas com pessoal correspondam a $60 \%$ do custeio total das unidades de saúde;

b) para a administração e apoio, estimou-se um custo equivalente a $10 \%$ do custo total de operação;

c) não se atribui ao PREVSAÚDE despesas de custeio referentes aos demais componentes do Programa.

\subsection{FINANCIAMENTO}

\subsubsection{DO INVESTIMENTO (tabela 15)}

Os recursos de investimento serão oriundos de fontes internas, no montante de Cr\$ 177.5 bilhões (80,5\%), e externas, no valor de Cr $\$ 43.1$ bilhões $(19,5 \%)$.

Os recursos de fontes externas, previstos a partir de 1981, no valor total de Cr\$ 43.1 bilhões, serão aportados por:

a) Banco Interamericano de Desenvolvimento - BID, mediante empréstimo no valor aproximado de US\$ 302 milhões, equivalente a Cr\$22.7 bilhões, advindos de recursos destinados pelo BID ao Brasil. As condições são favoráveis e específicas aos investimentos sociais: carência superior a 4 anos, juros privilegiados (6/7\% a.a.) e prazos superiores a 15 anos. Os empréstimos seriam realizados em três ou quatro momentos ao longo do período de execução do Programa;

c) Banco Internacional de Reconstrução e Desenvolvimento - BIRD, através de empréstimos no valor global de US\$ 144 milhões, e e-

$$
\text { [página 59] }
$$

quivalente a Cr\$ 10.8 bilhões.

c) Organizações Internacionais do Sistema das Nações Unidas, e organizações nacionais de cooperação internacional ou através da utilização da cooperação bilateral entre países, com um aporte de Cr\$ 9.6 bilhões, correspondentes a US\$ 128 milhões.

\subsubsection{FINANCIAMENTO DA OPERAÇÃO (tabelas 13, 14 e 15)}

A responsabilidade do financiamento da operação é exclusivamente interna. Os recursos necessários estão dentro das disponibilidades do Setor Público. Será necessário, porém, um remanejamento dos recursos disponíveis, especialmente pelo MPAS, substituindo formas atuais de aplicação de recursos na execução de serviços básicos. Este processo será realizado em forma progressiva, dentro dos prazos de implantação do PREVSAÚDE. 
Dos recursos totais - 1981 a 1986 - as fontes federais, em conjunto, aportarão 79,4\%, os Estados, cerca de $16,8 \%$ e os Municípios, aproximadamente, 3,8\%.

Os custos de operação com serviços próprios do MS e MPAS, incluídos no PREVSAÚDE, estão consignados nas tabelas 14 e 15.

No custeio das unidades do INAMPS participantes do PREVSAÚDE, já existentes, estão incluídos, além de Cr\$ 40.2 bilhões anuais atualmente comprometidos, Cr\$ 5.9 bilhões anuais a partir de 1982 até 1986, para complementação salarial do pessoal, de acordo com o Plano de Cargos e Salários do Programa.

A operação das novas unidades ambulatoriais a serem implantadas pelo INAMPS, com recursos do FAS, implicará nos seguintes gastos, já incluídos os decorrentes do Plano de Cargos e Salários: Cr\$ 4.8 bilhões em 1982; Cr\$ 9.6 bilhões em 1983; e Cr\$ 15.8 bilhões para cada um dos anos subsequentes.

Da participação total do MPAS no Programa, à CEME caberá, anualmente, Cr\$ 4.4 bilhões de seus recursos pró-

$$
\text { [página 60] }
$$

prios. O INAMPS participará em 1981 com Cr\$ 55,6 bilhões e alcançará Cr\$ 111.1 bilhões em 1986.

Está previsto um aumento progressivo dos recursos do Ministério da Saúde, o que representará, em 1986, um valor de Cr\$ 28.9 bilhões, a preços de 1981, dos quais Cr\$ 21.2 bilhões correspondendo a custeio de seus serviços próprios incluídos no PREVSAÚDE.

\section{[página não numerada]}

TABELA 1

PREVSAODE

CAPACIDADE INSTALADA DE SERVICOS BASICOS, NO SETOR POBLICO,

SEGUNDO AS GRALDES RBGIÖES, EM $1980(*)$ \&E PREVISTA PARA 1986

\begin{tabular}{|c|c|c|c|c|c|c|c|c|}
\hline \multirow{2}{*}{$R E G I X O$} & \multicolumn{2}{|c|}{ DE PAOTTO } & \multicolumn{2}{|c|}{$\begin{array}{c}\text { CONSULTORIO } \\
\text { MEDICO }\end{array}$} & \multicolumn{2}{|c|}{$\begin{array}{l}\text { CONSULTORIO } \\
\text { ODONTOLOGICO }\end{array}$} & \multicolumn{2}{|c|}{$\begin{array}{l}\text { LEITOS DE } \\
\text { UNIDADE MISTA }\end{array}$} \\
\hline & 1980 & 1986 & 1980 & 1986 & 1980 & 1986 & 1980 & 1986 \\
\hline NORTE & 370 & 1.720 & 650 & 1.400 & 190 & 330 & 850 & 1.650 \\
\hline NORDESTE & 2.300 & 4.760 & 3.800 & 9.800 & 1.370 & 2.080 & 2.000 & 3.600 \\
\hline SUDESTE & 940 & 2.200 & 9.250 & 14.400 & 1.890 & 3.570 & 400 & 2.000 \\
\hline sut & 340 & 1.970 & 2.700 & 6.150 & 1.020 & 1.400 & 250 & 1.250 \\
\hline CENTRO-OESTE & 80 & 1.080 & 1.030 & 2.080 & 320 & 160 & 500 & 1.500 \\
\hline BRASIL & 4.030 & 11.730 & 17.430 & 33.830 & 4.790 & 7.840 & 4.000 & 10.000 \\
\hline
\end{tabular}

(") - Dados do Levantamento de capacidade Instalac. do setor píblico de Saíde - IS/NPAS - 1980 
[página não numerada]

IABSA-2

PRBSAODE

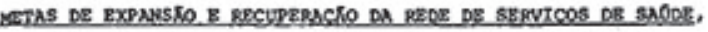

POR GRANDES RECTOES, EM $1912 \mathrm{E}$ TOTAL DO PESTOCO

\begin{tabular}{|c|c|c|c|c|c|c|c|c|c|c|c|c|c|c|c|c|}
\hline \multirow{2}{*}{$\sec 5$} & \multicolumn{2}{|c|}{80010 5a408 } & \multicolumn{2}{|c|}{ cossuxteato } & \multicolumn{2}{|c|}{10000} & \multicolumn{4}{|c|}{ 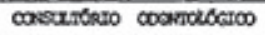 } & \multicolumn{4}{|c|}{ IRIJO UCronce Masm } & \multicolumn{2}{|c|}{ 100. woracta } \\
\hline & 13: & & & mas & & का & & & & 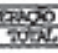 & & & & 20020 & $\begin{array}{l}\frac{1020}{1981} \\
19\end{array}$ & $\frac{100}{100 x}$ \\
\hline $\operatorname{scosex}$ & 200 & 1.350 & $\infty$ & 750 & 100 & 200 & 20 & 160 & so & 100 & 80 & 800 & 300 & 300 & 10 & $\infty$ \\
\hline secosests & 350 & 2.460 & 600 & 6.000 & 600 & 1.200 & 70 & $n 0$ & 360 & 600 & 160 & 1.600 & 200 & 200 & 40 & 400 \\
\hline $\operatorname{sucss}$ & 290 & 1.260 & 510 & 5.150 & 1.500 & 3.000 & 160 & 1.680 & 470 & 940 & 160 & 1.600 & 130 & 230 & 60 & 620 \\
\hline sux & 240 & 1.630 & 360 & 3.450 & 400 & 900 & 40 & 380 & 250 & 520 & 60 & 2.000 & - & - & 20 & 260 \\
\hline canc-cesre & 150 & 1.000 & 100 & 1.050 & 280 & 300 & 20 & 180 & 20 & 260 & 220 & 2.000 & 200 & 200 & 20 & 90 \\
\hline vensin. & 1.130 & 7.700 & 2.630 & 26.400 & 2.800 & 5.600 & 310 & 3.050 & 1.190 & 2.390 & 600 & 6.000 & 1.330 & 1.330 & 160 & 1.430 \\
\hline
\end{tabular}

[página não numerada]

$\operatorname{TABELA\quad 3}$

PREVSAODE

IRTAS OE PRODUCTO DOS SERVICOS BSSICOS, SBGUNOO GRANDES

REGIOES, EM 1981 NO PTNAI DO PERIODO

(B) 1.000 ATIVIDNCES)

\begin{tabular}{|c|c|c|c|c|c|c|c|c|c|c|}
\hline \multirow{2}{*}{ REGrRo } & \multicolumn{2}{|c|}{$\begin{array}{l}\text { cassuma ronta } \\
\text { BKstca (1). }\end{array}$} & \multicolumn{2}{|c|}{ 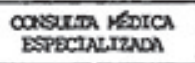 } & \multicolumn{2}{|c|}{$\begin{array}{l}\text { Araponemo } \\
\text { DE urcsicti }\end{array}$} & \multicolumn{2}{|c|}{$\begin{array}{c}\text { cansurnas } \\
\text { cosindertess }\end{array}$} & \multicolumn{2}{|c|}{ 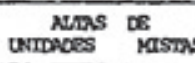 } \\
\hline & 1981 & 1986 & 1981 & 1966 & 1981 & 1986 & 1981 & 1986 & 1981 & 1986 \\
\hline Wores & 4.745 & 10.219 & 950 & 2.044 & 710 & 1.533 & 1.344 & 2.112 & 43 & 83 \\
\hline toresestr & 22.740 & 69.112 & 4.550 & 13.942 & 3.411 & 10.457 & 10.457 & 14.216 & 100 & 180 \\
\hline sucesse & 87.625 & 101.989 & 13.525 & 20.398 & 10.144 & 15.298 & 13.120 & 27.848 & 20 & 100 \\
\hline ser. & 19.710 & 46.868 & 3.950 & 9.374 & 2.957 & 7.030 & 6.784 & 8.960 & 12 & 62 \\
\hline $\cos m 0-\cos n=$ & 7.519 & 16.851 & 1.500 & 3.370 & 1.126 & 2.528 & 2.176 & 2.944 & 25 & 75 \\
\hline Bgasn & 122.339 & 245.639 & 24,475 & 49.128 & 18.350 & 36.646 & 33.861 & 46.080 & 200 & 500 \\
\hline
\end{tabular}

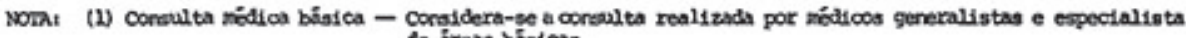
de areats bistcen. 
[página não numerada]

\begin{tabular}{|c|c|c|c|c|c|c|c|c|c|c|}
\hline & & & $\begin{array}{l}\text { getas } \\
\text { sexvy }\end{array}$ & 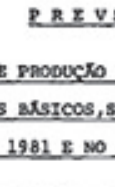 & 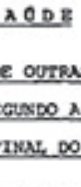 & 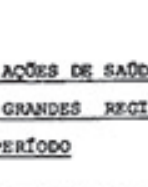 & $\frac{\cos x y}{40 x}$ & $\operatorname{con} 10$ & 900 pecal & \\
\hline \multirow{3}{*}{$\operatorname{REc} \mathrm{COs}$} & \multirow{2}{*}{\multicolumn{2}{|c|}{ 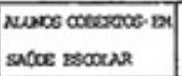 }} & \multirow{2}{*}{\multicolumn{2}{|c|}{ 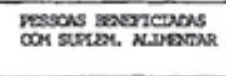 }} & \multicolumn{6}{|c|}{ 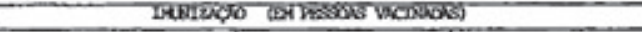 } \\
\hline & & & & & $P O L 1$ & $4 \times 82 \times 78$ & $\begin{array}{l}\text { SAsw:0, } \\
\text { curwo: }\end{array}$ & 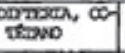 & TEve: & $\operatorname{assixas}$ \\
\hline & 198 & 1985 & 1981 & 1985 & 1981 & 1986 & 1981 & 1980 & 1981 & $19 \mathrm{es}$ \\
\hline uces: & 133 & 507 & 210 & 250 & 1.060 & 1.525 & sos & 1.525 & 126 & 7.659 \\
\hline acousns & 247 & 2.554 & 1.980 & 4.200 & 5.083 & 8.285 & 3.050 & 8.295 & 629 & 3.58 \\
\hline $90 \mathrm{DER}$ & 6os & $4.7 \%$ & $m$ & 68 & 6.618 & 9.347 & 3.434 & 9.367 & 715 & 4.542 \\
\hline 500 & 290 & 1.578 & 270 & 400 & 2.869 & 4.010 & 1.479 & 4.010 & 306 & 1.965 \\
\hline osmo-cesss & 91 & 824 & 15s & 500 & 1.256 & $1.7 n$ & 658 & 2.774 & 235 & 657 \\
\hline Basn & 1.865 & 10.603 & 3.000 & 6.120 & 17.648 & 24.961 & 9.216 & 24.941 & 1.901 & $18.7 \mathrm{I}$ \\
\hline
\end{tabular}

[página não numerada]

\begin{tabular}{|c|c|c|c|c|c|c|c|c|c|c|}
\hline \multicolumn{11}{|c|}{ 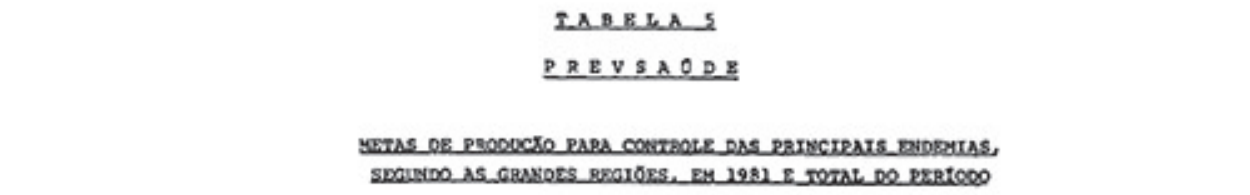 } \\
\hline \multirow{2}{*}{ 2xGIOES } & \multicolumn{2}{|c|}{ 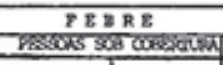 } & \multicolumn{2}{|c|}{ 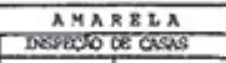 } & \multicolumn{2}{|c|}{ 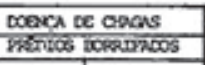 } & \multicolumn{2}{|c|}{ 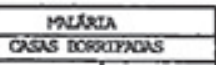 } & \multicolumn{2}{|c|}{ 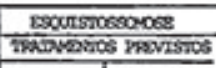 } \\
\hline & 1981 & notos. & 1981 & 20TNL & 1981 & TORE & 1991 & ropt. & 1961 & 2000 . \\
\hline SO6KI8 & 2.507 .000 & 2.813 .200 & 287.600 & 5.018 .000 & - & - & 1.528 .000 & 7.631 .000 & 500 & 2.500 \\
\hline serossn: & 180.000 & 232.670 & 1.217 .900 & 7.758 .900 & 429.500 & $2.7 \times 6.700$ & 1.765 .000 & 6.654 .000 & 460.400 & 1.644 .500 \\
\hline scoesx & 120.000 & 136.000 & 4.870 .000 & 29.417 .500 & 228.750 & $1,468,000$ & 73.000 & 198,000 & 17.100 & 63.600 \\
\hline sxy & 105.000 & 124.400 & 54.000 & 2.695 .200 & 104.500 & 762.900 & 217.000 & 323.000 & 26.000 & 26.000 \\
\hline mano-cessz & 1.318 .000 & 1.536 .460 & 1.020 .000 & 2.758 .900 & 66.900 & 461.900 & 902.000 & 3.766 .000 & - & - \\
\hline mins & 4.230 .000 & 4.844 .190 & 8.459500 & 53.609 .500 & 809.400 & 5.429 .500 & $4,365.000$ & 18.572 .000 & 506.000 & 1.786 .600 \\
\hline
\end{tabular}


[página não numerada]

\section{IABELA 6 \\ PREVSAUDE}

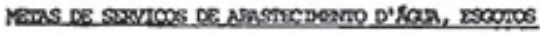

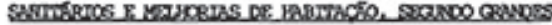

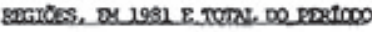

\begin{tabular}{|c|c|c|c|c|c|c|}
\hline \multirow{3}{*}{$R E G I 8 \mathrm{ES}$} & \multirow{2}{*}{\multicolumn{2}{|c|}{$\begin{array}{l}\text { AsAstracpono D'RaA } \\
\text { PESSOASSERVIDAS }\end{array}$}} & \multirow{2}{*}{\multicolumn{2}{|c|}{ 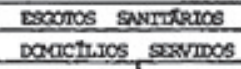 }} & \multirow{2}{*}{\multicolumn{2}{|c|}{ 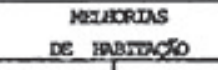 }} \\
\hline & & & & & & \\
\hline & 1931 & TODDL & 1981 & TOSL & 1981 & 30000 \\
\hline NORTE & 34.000 & 422.500 & 3.100 & 39.000 & 1.000 & 12.500 \\
\hline NORDESTE & 705.000 & 8.821 .300 & 69.000 & 861.080 & 12. 800 & 147.500 \\
\hline suorste & 234.000 & 2.923 .900 & 28.700 & 233.920 & 6.400 & 80.000 \\
\hline sul & 107.000 & 1.343 .600 & 8.600 & 107.550 & 3.800 & 47.500 \\
\hline CEATRO-OESTE & 93.000 & 1.167 .500 & 7.400 & 92.740 & 1.800 & 22.500 \\
\hline BRASIL & 1.173 .000 & 14.678 .800 & 105.800 & 1.334 .290 & 24.800 & 310.000 \\
\hline
\end{tabular}

[página não numerada]

\begin{tabular}{|c|c|c|c|c|c|c|c|c|c|c|}
\hline & & $\begin{array}{l}\text { Tas Do } \\
\text { As Geas }\end{array}$ & $\begin{array}{l}\text { CARAC } \\
\text { CDES DI }\end{array}$ & PRE & 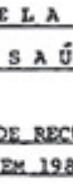 & 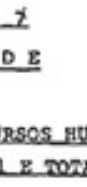 & Noses, & $\frac{1 D Q}{6}$ & & \\
\hline \multirow{3}{*}{ REGIOES } & \multicolumn{6}{|c|}{ TRETUMNERTO \& RKCICLUGEM } & \multirow{2}{*}{\multicolumn{2}{|c|}{ pts-asubectio }} & \multirow{2}{*}{\multicolumn{2}{|c|}{$=0=A 2$}} \\
\hline & \multicolumn{2}{|c|}{ 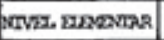 } & \multicolumn{2}{|c|}{ NAver vom } & \multicolumn{2}{|c|}{ 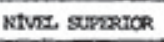 } & & & & \\
\hline & 1981 & $\cos$ & 1921 & 20ML. & 1981 & TODU & 1981 & SODNL & 2981 & TOMDS: \\
\hline norTB & 850 & 8.600 & 460 & 4.800 & 300 & 3.000 & 20 & 200 & 1.200 & 17.100 \\
\hline MORDESTE & 4.100 & 41.600 & 2.870 & 28.200 & 1.940 & 19.400 & 450 & 4.500 & 9.300 & 94.200 \\
\hline SUDESTE & 4.800 & 48.500 & 3.800 & 38.000 & 2.820 & 28.2000 & 510 & 5.100 & 11.930 & 119.800 \\
\hline sur & 2.300 & 23.600 & 1.730 & 17.300 & 1.230 & 12.300 & 270 & 2.700 & 5,530 & 55.900 \\
\hline CEATRO-OESTE & 950 & 9.500 & 670 & 6.200 & 440 & 4.400 & 90 & 900 & 2.150 & 21.500 \\
\hline zoasrz & 13.000 & 131.800 & 9.550 & 95.500 & 6.730 & 67.300 & 1.390 & 13.900 & 30.670 & 308.500 \\
\hline
\end{tabular}


[página não numerada]

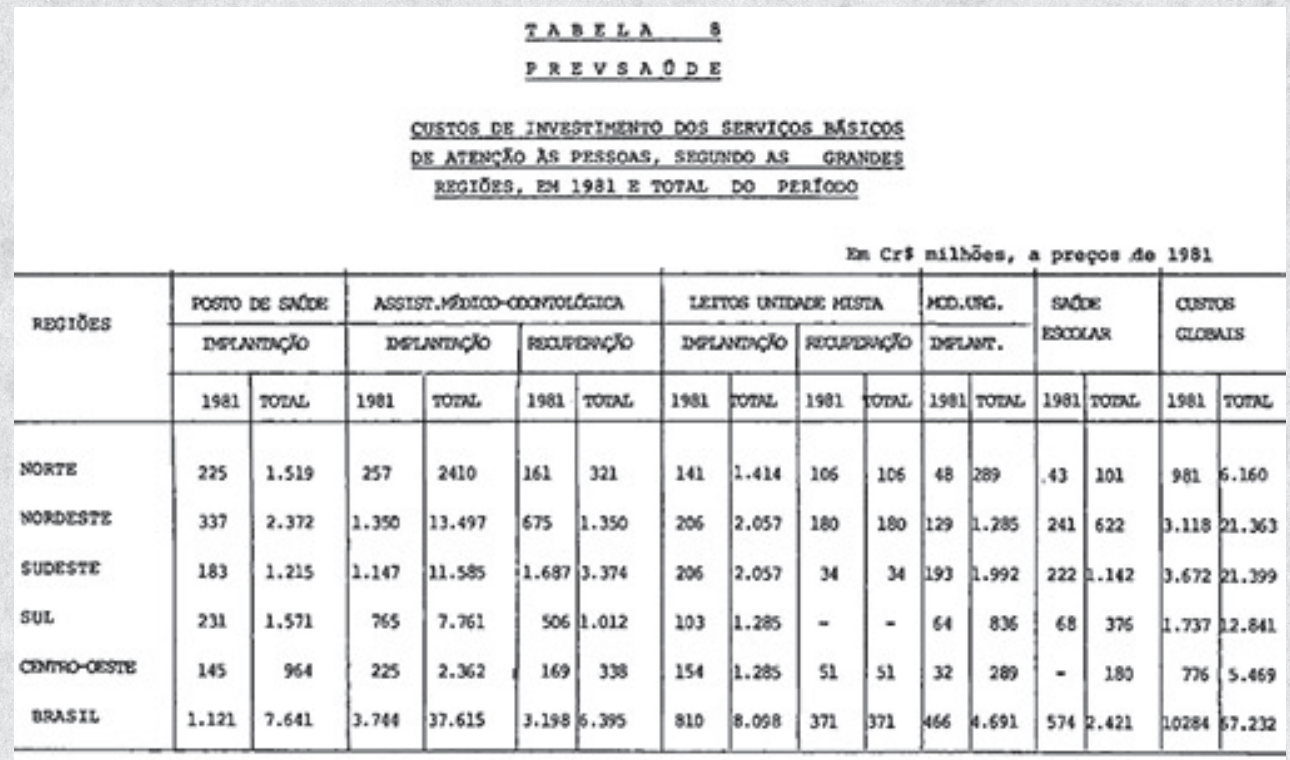

[página não numerada]

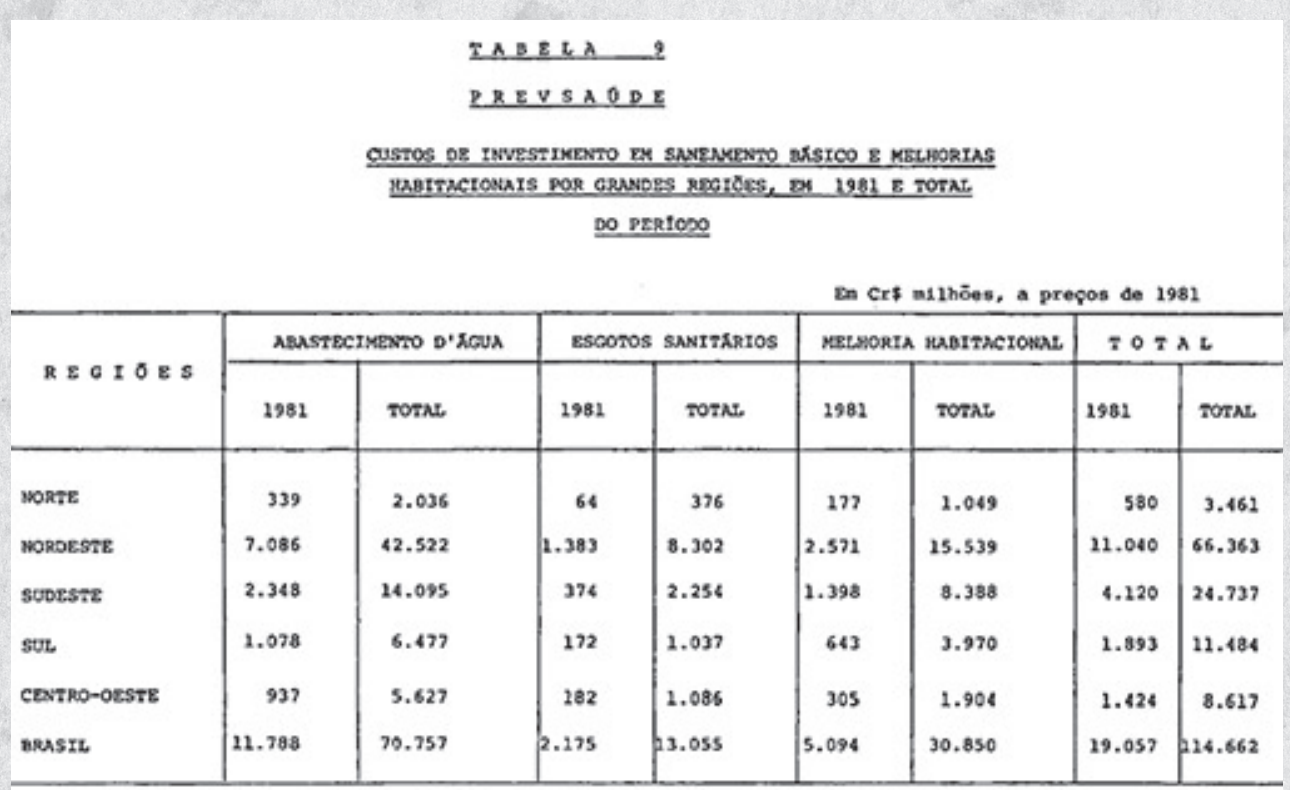


[página não numerada]

\begin{tabular}{|c|c|c|c|c|c|c|c|c|c|c|c|c|c|c|}
\hline & & ass & os 08 & $\frac{\text { nurst: }}{\mathrm{s}}$ & $\begin{array}{r}\frac{7}{8} \\
\cos 20 \\
\operatorname{sen} 20\end{array}$ & 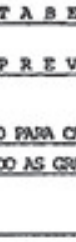 & $\begin{array}{l}\text { LA } \\
\text { s A } 0 \\
\text { axpes } 8\end{array}$ & 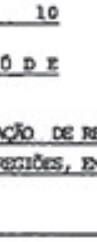 & $\frac{10098}{1931}$ & 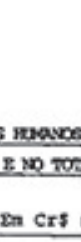 & $\frac{g \text { Crras }}{D P B S}$ & $\begin{array}{l}\text { acrivinaces } \\
\text { tco00 } \\
\text { a prepos }\end{array}$ & de 1981 & \\
\hline \multirow{3}{*}{$R E G I 0 x s$} & \multicolumn{12}{|c|}{ RECURSOS HOMA MOS } & \multirow{2}{*}{\multicolumn{2}{|c|}{ 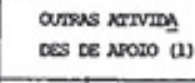 }} \\
\hline & \multicolumn{2}{|c|}{ EDENaR } & \multicolumn{2}{|c|}{ N2Dto } & \multicolumn{2}{|c|}{ STENTCR } & \multicolumn{2}{|c|}{ POS-canoucto } & \multicolumn{2}{|c|}{$\begin{array}{c}\text { Dents } \\
\text { Acritosecs }\end{array}$} & \multicolumn{2}{|c|}{ sations. } & & \\
\hline & 981 & oas & 2981 & some & 2901 & TOEN & 1901 & TOR2 & 1981 & fores & 1981 & pores & 2981 & actos \\
\hline NOR $=E$ & 22 & 219 & 18 & 274 & 10 & 100 & 10 & 92 & 24 & 236 & 84 & 819 & 103 & 874 \\
\hline wotbesre & 233 & . .338 & 104 & 2.038 & 63 & 623 & 59 & 599 & 156 & .558 & $\$ 16$ & 5.258 & 797 & 8.774 \\
\hline sUDEstE & 156 & 2.55s & 138 & 1.377 & 90 & 906 & 66 & 667 & 207 & 8.073 & 657 & 6.581 & 1.003 & 3.522 \\
\hline sez & 82 & 818 & 63 & 625 & 40 & 395 & 35 & 358 & 97 & 958 & 316 & 3.154 & 488 & 4.152 \\
\hline centho- coss & 31 & 304 & 24 & 244) & 24 & 140 & 13 & 124 & 35 & 347 & 117 & 2.159 & 180 & 1.530 \\
\hline BRAstz & 24 & 4237 & 347 & 3.4580 & 227 & 2.164 & 183 & 1.840 & 519 & 5.172 & 2690 & 16.871 & 2.571 & 21852 \\
\hline
\end{tabular}

motar (1) - Inclu1 Desenvolvinento Instituclonal, e Pesquiss e Desenvolvisento Tecnológico.

[página não numerada]

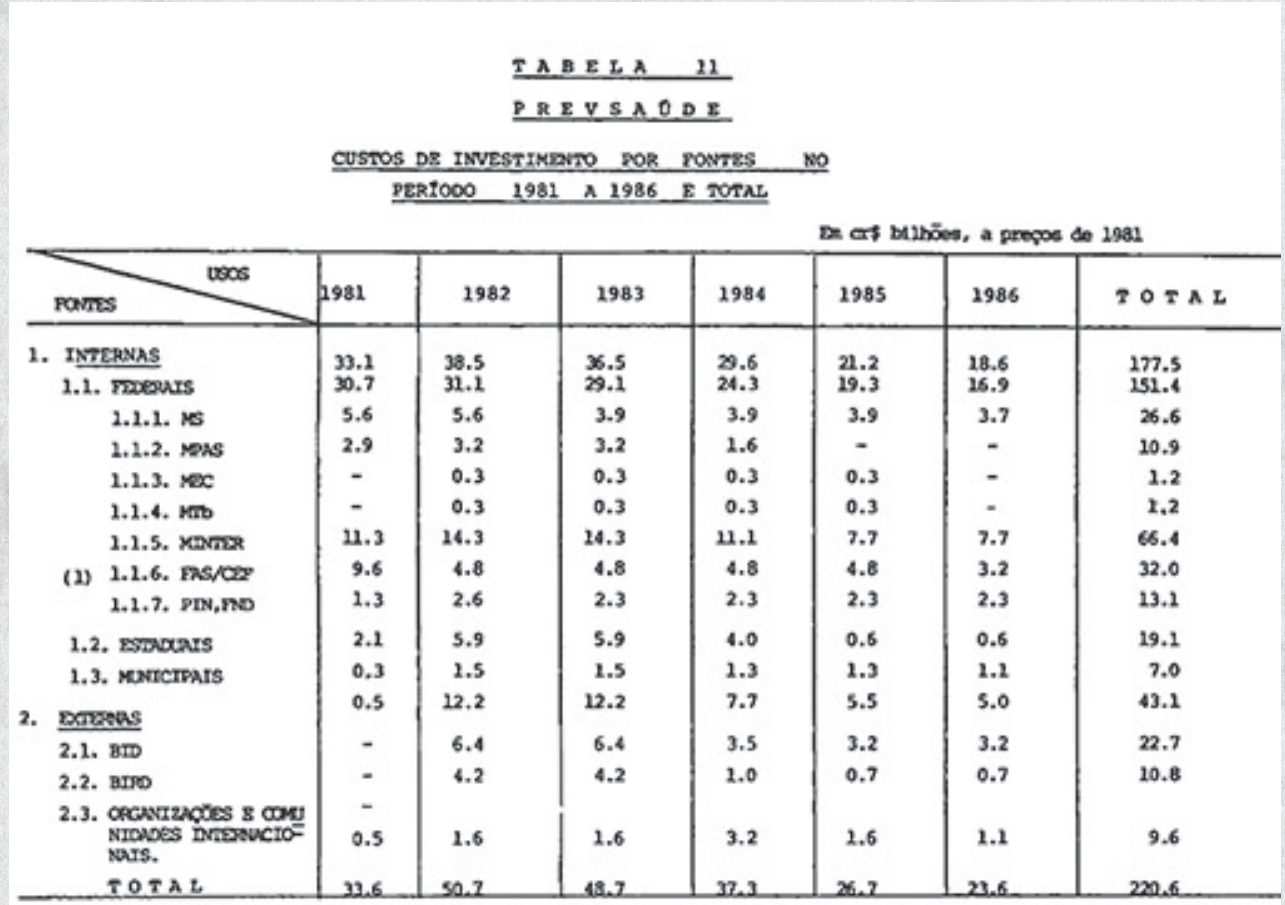

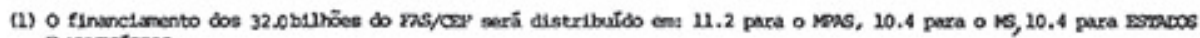
$\Sigma$ veactorces. 
[página não numerada]

\section{TABELA_ 12 \\ $\operatorname{RgVSAODE}$}

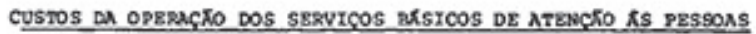

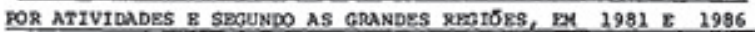

\begin{tabular}{|c|c|c|c|c|c|c|c|c|c|c|c|c|c|c|}
\hline \multirow{2}{*}{$R E G I \delta E S$} & \multicolumn{2}{|c|}{ posso te acos } & \multicolumn{2}{|c|}{ NSS.MED.0000rT. } & \multicolumn{2}{|c|}{ Lerros O.M. } & \multicolumn{2}{|c|}{ SNOOE ESCOCRR } & \multicolumn{2}{|c|}{ woo.tos. } & \multicolumn{2}{|c|}{ Tex. E NeOro } & \multicolumn{2}{|c|}{ asnos gromIs } \\
\hline & 1981 & 1906 & 1981 & 1986 & 1981 & $15 e 6$ & 1961 & 1965 & 1931 & 1996 & 1981 & 1506 & 1981 & 1985 \\
\hline werts & 175 & 829 & 2.478 & 5.444 & 534 & 1.057 & 9 & 374 & 132 & 810 & 342 & 852 & 3.757 & 9.366 \\
\hline MORDESTE & 1.087 & $2.25 \%$ & 14.486 & 8.107 & 1.257 & 2.306 & 641 & 2.595 & 529 & 5.399 & 1.801 & 5.069 & 19.801 & 55.761 \\
\hline SUDESTE & 444 & 1.060 & 35.263 & $\$ 5.994$ & 250 & 1.281 & 482 & 3.423 & 794 & 8.363 & 3.724 & 7.012 & 10.957 & 77.138 \\
\hline sut & 161 & 950 & 10.293 & 23.914 & 257 & 800 & 132 & 1.019 & 265 & 3.589 & 1.101 & 3.027 & 12.109 & 33.299 \\
\hline caxtro-osers & 38 & 521 & 3.926 & 8.087 & 315 & \$1 & 65 & 604 & 132 & 1.215 & 447 & 1.139 & 4.923 & 12.527 \\
\hline Rasin & 1.905 & 5.655 & 66.466 & 31.546 & 2.513 & 6.405 & 1.416 & 8.005 & 1.852 & 19.38 & 0.415 & 17.001 & 81547 & 188.091 \\
\hline
\end{tabular}

\section{[página não numerada]}

\section{IABELA 13 \\ PREVSAODE}

CUSTOS DE OPERACHO (1), POR FONTES, NO PERTOOO DE 1981 a 1986

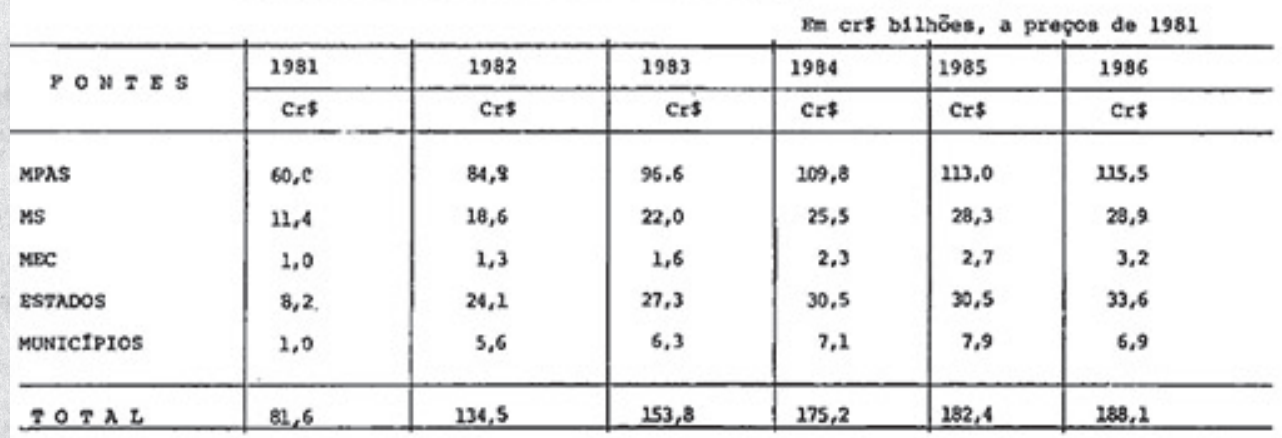

(1) Wo período de 1981 a 1984; ocupaçäo plena da capacidade jă instalada da redo de Sorviços B5a1cos e operaçāo plena das unidades do INMmps a seres expandidas. No perlodo de 1981 a 2985 ; operą̧̄o plena do Pass, confore o Decreto a $84.219 / 79$. No período de 1981 a 1986 ; operação plena das unidades dos Estados e Municiplos a sorea expandidas. 


\section{[página não numerada]}

IARER M

PREVSAODE

CUSTOS DE OPERACTO COM SERVICOS PROPRIOS DO MPAS E MS IMCLUTDOS NO PREVSAODE, NO PERTODO OR 1981 a 1986

Ea cr\$ bilnōes a preços de 1981

\begin{tabular}{|c|c|c|c|c|c|c|}
\hline PON TE S & 1981 & 1982 & 1983. & 1984 & 1985 & 1986 \\
\hline MPAS/INUNPS & $40,2+4,7$ & $50.99^{+}$, & $55,2+15,8$ & 61,9 & 61.9 & 61,9 \\
\hline MS & 12,4 & 12.5 & 15,0 & 18.0 & 20,2 & 21,2 \\
\hline
\end{tabular}

[página não numerada]

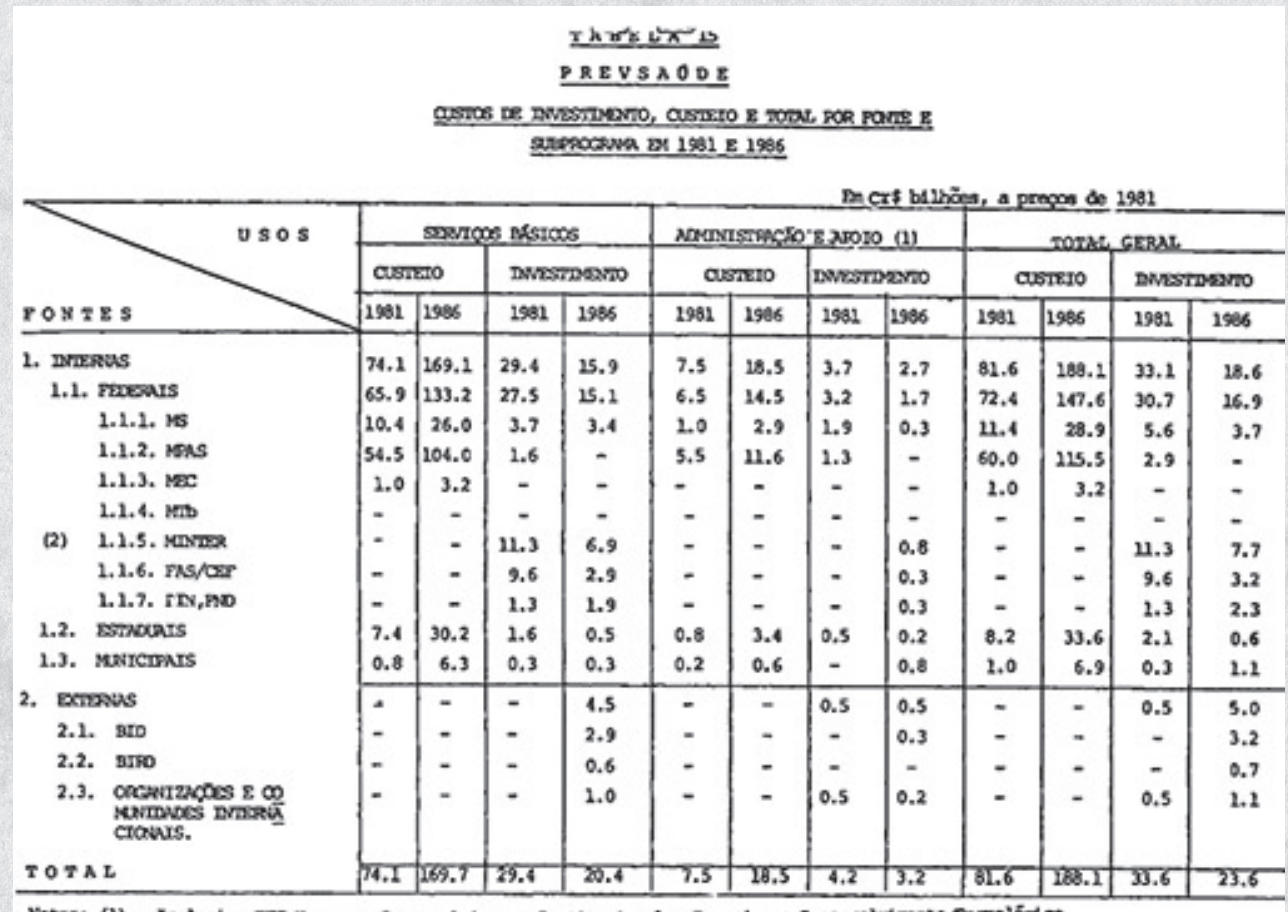

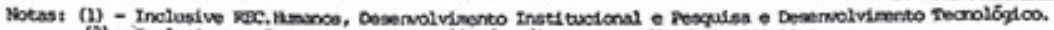

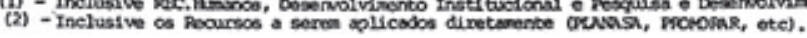


[página não numerada]

TABELA 16

PREVSAODE

CUSTOS POR SUBPROGRAMAS E POR NATUREZA DE

DESPESA EM 1981 E NO TOTAL DO PERTODO

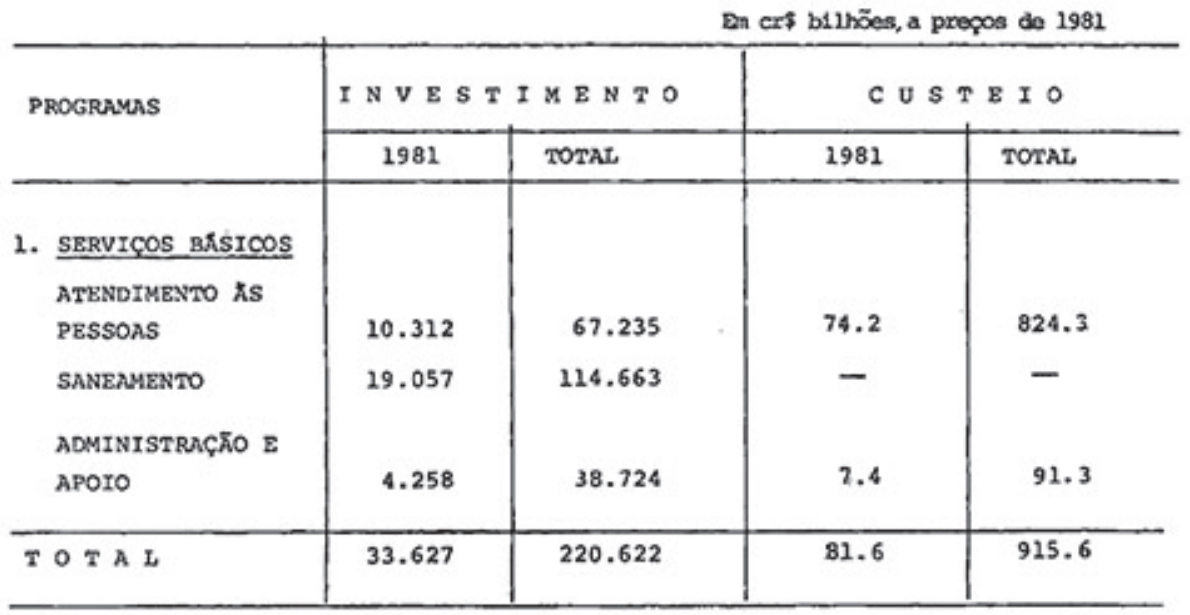

